\title{
Review \\ Nano-Biochar as a Sustainable Catalyst for Anaerobic Digestion: A Synergetic Closed-Loop Approach
}

\author{
Lalit Goswami ${ }^{1,+}{ }^{D}$, Anamika Kushwaha ${ }^{1,+}$, Anju Singh ${ }^{2}$, Pathikrit Saha ${ }^{1}$, Yoseok Choi ${ }^{1}$, \\ Mrutyunjay Maharana ${ }^{3}$ (D), Satish V. Patil ${ }^{4}$ and Beom Soo Kim ${ }^{1, *(D)}$
}

1 Department of Chemical Engineering, Chungbuk National University, Cheongju 28644, Korea; lalitgoswami660323@gmail.com (L.G.); kushwaha.anamika@gmail.com (A.K.); pathikritsaha89@gmail.com (P.S.); y.choi@chungbuk.ac.kr (Y.C.)

2 Department of Chemical Engineering, Babu Banarsi Das National Institute of Technology and Management, Lucknow 227105, India; anjusinghch1711@gmail.com

3 School of Electrical Engineering, Xi'an Jiaotong University, Xi'an 710049, China; maharana@xjtu.edu.cn

4 School of Life Sciences, Kavayitri Bahinabai Chaudhari North Maharashtra University, Jalgaon 425001, India; satish.patil7@gmail.com

* Correspondence: bskim@chungbuk.ac.kr; Tel.: +82-43-261-2372

+ These authors contributed equally to this work.

Citation: Goswami, L.; Kushwaha, A.; Singh, A.; Saha, P.; Choi, Y.; Maharana, M.; Patil, S.V.; Kim, B.S. Nano-Biochar as a Sustainable

Catalyst for Anaerobic Digestion: A Synergetic Closed-Loop Approach. Catalysts 2022, 12, 186. https:/ / doi.org/10.3390/catal12020186

Academic Editor: Keith Hohn

Received: 30 December 2021

Accepted: 30 January 2022

Published: 1 February 2022

Publisher's Note: MDPI stays neutral with regard to jurisdictional claims in published maps and institutional affiliations.

Copyright: (C) 2022 by the authors. Licensee MDPI, Basel, Switzerland. This article is an open access article distributed under the terms and conditions of the Creative Commons Attribution (CC BY) license (https:// creativecommons.org/licenses/by/ $4.0 /)$.

\begin{abstract}
Nowadays, the valorization of organic wastes using various carbon-capturing technologies is a prime research area. The anaerobic digestion (AD) technology is gaining much consideration in this regard that simultaneously deals with waste valorization and bioenergy production sustainably. Biochar, a well-recognized carbonaceous pyrogenic material and possessing a broad range of inherent physical and chemical properties, has diverse applications in the fields of agriculture, health-care, sensing, catalysis, carbon capture, the environment and energy. The nano-biochar-amended anaerobic digestion approach has intensively been explored for the past few years. However, an inclusive study of multi-functional roles of biochar and the mechanism involved for enhancing the biogas production via the $\mathrm{AD}$ process still need to be evaluated. The present review inspects the significant role of biochar addition and the kinetics involved, further focusing on the limitations, perspectives, and challenges of the technology. Additionally, the techno-economic analysis and life-cycle assessment of biochar-aided $\mathrm{AD}$ process for the closed-loop integration of biochar and $\mathrm{AD}$ and possible improvement practices are discussed.
\end{abstract}

Keywords: biochar-amended process; mechanism involved; kinetics; techno-economic analysis; zero-waste approach

\section{Introduction}

Presently, the human population has crossed 7.2 billion and is expected to reach between $9.6-12.3$ billion by 2100 [1]. This tremendous population growth is further accompanied by enormous industrial development and unprecedented consumption of energy, enhancing the stress on natural resources at a startling level $[2,3]$. To meet this rising demand, over-exploitation of fossil-based energy is occurring, with deleterious environmental and societal impacts [4-8]. Renewable energy is recognized as a sustainable option to overcome all these challenging issues. Sources such as wind, hydro, geothermal, solar energy, biogas, microbial fuel cells, bioethanol, biodiesel, biohydrogen, etc. have been explored to find a viable solution [9]. Amidst these available options, some utilize silver, titanium, platinum, ruthenium, nickel, and other metal oxides as catalysts on a huge scale [10,11]. Though these metals are very efficient, there is a hunt for sustainable catalyst materials that are cost-effective, efficient, eco-friendly, and widely available.

Biomass is currently the most sustainable option available, and has been widely explored for synthesizing various sustainable materials such as carbon fibers, biochar, activated carbon, graphene, etc. that show tremendous applicability in the energy sector [12,13]. 
Biochar is a carbonaceous material that is produced via the thermochemical decomposition of organic materials [14]. It is a highly porous, amorphous material with a good surface area containing various functional groups, while displaying stable physicochemical properties and biocompatibility, and easy to further modify in accordance with the particular need $[15,16]$. The properties of biochar for various application such as bioremediation, energy storage, catalysis, agriculture, carbon capture, wastewater treatment, pharmaceutical, electrodes, cosmetics, etc. rely on the production process, kind of feedstock and operating parameters used [17-21].

During the past decade, biochar has also been utilized in the anaerobic digestion (AD) process. The AD process has ability to use organic biomass and wastes for the production of biogas (containing $\sim 60 \%$ methane) and high quality of bio-fertilizers [22,23]. This conversion is purely dependent on to the synergistic metabolic activities of the prevailing microbial consortia within the digester and has to be further maintained under steady state conditions for the best performance. Various electron transfers amongst the similar partners are required to avoid the longer acclimatization period along with the high substrate consumption rate [24]. The direct interspecies electron transfer (DIET) is recognized as more rapid and stable pathway where the transfer of electrons takes place between the syntrophic bacteria to the methanogenic archaea [25].

Recently, researchers have started focusing on non-biological conductive materials such as magnetite, biochar, granular activated carbon, etc. to enhance the DIET performance. Biochar has the ability to enhance the DIET via a conduction-based mechanism that channels the electron flow between the electron-donor and electron-acceptor ends [22]. In addition, biochar supplementation leads to a simple and efficient microbial community possessing the enriched and equilibrated DIET. Biochar-aided anaerobic digestion mediates the formation and degradation of intermittent acids and leads to the enrichment of methanogenic archaea, shortening the lag phase, and enhancing the methane yield [26].

Henceforth, the present review aims to summarize the recent advancements regarding the utilization of nano-biochar in anaerobic digestion processes. This review's focus is on the application of nano-biochar as a sustainable nano-catalyst for the production of renewable energy, particularly by anaerobic digestion. Here, we have considered the biochar according to its particle size, i.e., macro-biochar $(>1 \mu \mathrm{m})$, colloidal biochar $(1 \mu \mathrm{m}-$ $100 \mathrm{~nm})$, and nano-biochar (<100 nm). The role, kinetics, mechanism(s) involved, and possible improvements along with the closed-loop integration of nano-biochar and AD have also been discussed. The review also covers the involvement of techno-economic and environmental life-cycle assessments for moving forward with the least limitations. A network visualization of terms associated with anaerobic digestion and biochar with at least 10 occurrences of the associated keywords is represented in Figure 1. It depicts the present trends in research and development regarding the application of biochar in association with the anaerobic digestion in the Web of Science. Here, the various colors of the nodes represent the different clusters whereas the size of each bubble depicts its frequency of occurrence. 


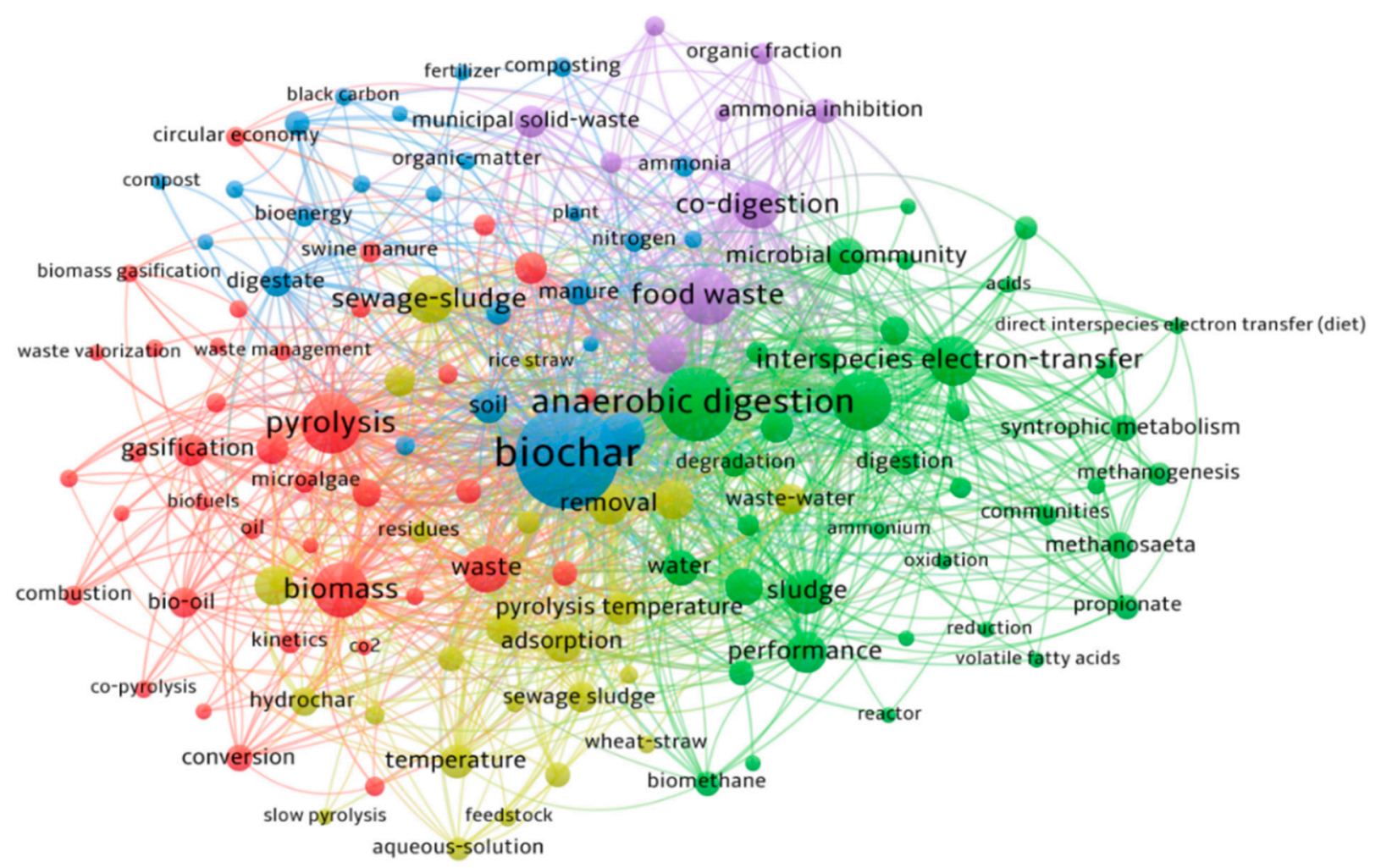

Figure 1. Network visualization of terms associated with anaerobic digestion and biochar.

\section{Application of Nano-Biochar in Renewable Energy}

Conventionally, biochar has been utilized for soil amendment and bioremediation applications. In this section, we discuss the recent advances in various techniques for biochar application as a catalyst in enhancing renewable energy production. Figure 2 illustrates the emerging applications of biochar for renewable energy. The biomass-derived nano-biochar can be utilized as an electrode in microbial fuel cells (MFCs) and as a catalyst for improving biodiesel and hydrogen generation. The applications of nano-biochar are very dependent on its physicochemical properties such as the biomass composition, biomass-conversion technologies and conditions, $\mathrm{pH}$ buffering capability, the presence of various trace elements, etc. [27]. Nano-biochar used in MFC creates a favorable environment for microbial growth and biofilm formation. Further, nano-biochar possessing higher surface area, porosity, and functional groups is more appropriate for microbial film formation, leading to electricity generation in MFC. Owing to the heterogeneous nature of nano-biochar, several techniques are utilized nowadays for its activation for nano-biochar to act as catalyst in a more effective, economical, and reutilizable mode.

\subsection{Nano-Biochar for Microbial Fuel Cell}

MFCs might be a viable solution for the global energy concerns, containing anodic and cathodic chambers that are further separated via a proton exchange membrane and utilizing microbes as a catalyst for converting chemical energy into electrical energy. Microbes utilize organic matter for their metabolic activities, while simultaneously releasing numerous intermediate metabolites that undergo redox reactions to generate electrons and protons $[28,29]$. The electrons generated in the anodic chamber under anaerobic conditions move towards the cathode while the proton moves towards the cathode via a proton exchange membrane. Several microorganisms, such as Shewanella, Clostridium, Rhodospirillum, etc., have already been reported in relation to the MFC applications [28]. Here, the bio-electricity generated depends on numerous factors, viz., substrate, rate of electron transfer, electrode performance, rate of oxygen reduction, and external operating conditions. In addition, the performance of the electrode material depends on its nature 
of physical and chemical properties. During the upscaling of MFCs, low current output and high cost are the major limitations [30]. The electrodes represent $20-50 \%$ of the overall cost of a MFC as they are usually made of non-renewable materias, viz., stainless steel, $\mathrm{Ni}, \mathrm{Cu}$, etc. These materials further require surface modifications for biofilm formation and electron transfer [31]. Table 1(a) summarizes the utilization of nano-biochar for MFCs. Further, researchers are utilizing sediment MFCs, also known as benthic MFCs (in some cases), applied in the natural systems such as constructed wetland [32]. The energy output from such MFCs is generally very low (e.g., $10-50 \mathrm{~mW} \mathrm{~cm}^{-2}$ ). Coconut shell-derived biochar-amended sediment MFC improved the power generation 2-10 times along with the increased total organic carbon (TOC) removal [33]. Also, soil-based MFCs have good performance in low-power continuous energy sources along with the soil remediation application [34]. Li et al. [35] utilized a chicken manure, wheat straw and wood sawdust-derived biochar-amended soil MFC for the biodegradation of petroleum hydrocarbons.

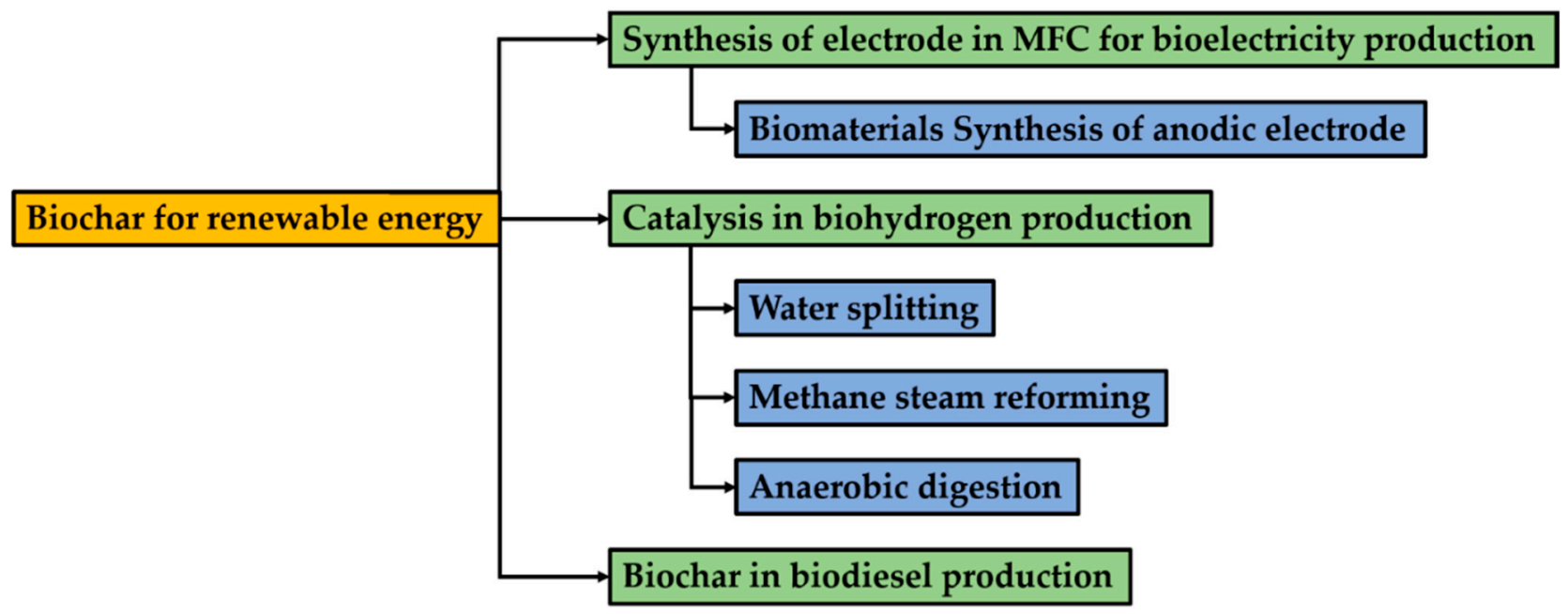

Figure 2. Utilization of biochar for renewable energy production.

Table 1. Application of nano-biochar as catalysts for the production of different renewable energy. (a) Nano-biochar for MFC for bioelectricity production; (b) Nano-biochar for anaerobic digestion for hydrogen production; (c) Nano-biochar for biodiesel production.

(a)

\begin{tabular}{|c|c|c|c|c|}
\hline \multicolumn{5}{|c|}{ As Anode } \\
\hline Biomass & Preparation & Comments & Power Density & References \\
\hline Chestnut shell & $900^{\circ} \mathrm{C}, 2 \mathrm{~h}$ & $\begin{array}{l}\text { Activation with } \mathrm{KOH} \text { modified } \\
\text { microporous structure with reduced } \mathrm{O} \\
\text { and } \mathrm{N} \text { content that is beneficial for } \\
\text { charge transfer and microbial adhesion }\end{array}$ & $23.6 \mathrm{Wm}^{-3}$ & {$[36]$} \\
\hline $\begin{array}{l}\text { Microalgal sludge } \\
\text { (MSB) }\end{array}$ & $800^{\circ} \mathrm{C}, 2 \mathrm{~h}$ & $\begin{array}{l}\text { Cobalt and chitosan were used as a } \\
\text { mediator for electron transfer by } \\
\text { immobilization on MSB } \\
\text { (MSB/Co/chitosan). }\end{array}$ & $3.1 \mathrm{mWcm}^{-2}$ & [37] \\
\hline Microalgal & $900^{\circ} \mathrm{C}, 1 \mathrm{~h}$ & Contains intrinsic $\mathrm{N}$ and $\mathrm{P}$ & $12.8 \mathrm{Wm}^{-3}$ & {$[38]$} \\
\hline $\begin{array}{l}\text { Deoiled Azolla } \\
\text { biomass }\end{array}$ & $600{ }^{\circ} \mathrm{C}, 3 \mathrm{~h}$ & $\begin{array}{l}\text { Nano-biochar was activated with } \mathrm{KOH} \\
\text { at } 1: 4 \text { ratio at } 600^{\circ} \mathrm{C} \text { for } 2 \mathrm{~h} . \\
\text { Bio-electrode was prepared by using } 5 \% \\
\text { polyvinylidene fluoride (PVDF). }\end{array}$ & - & [39] \\
\hline
\end{tabular}


Table 1. Cont.

(a)

\begin{tabular}{|c|c|c|c|c|}
\hline \multicolumn{5}{|c|}{ As Anode } \\
\hline Biomass & Preparation & Comments & Power Density & References \\
\hline \multicolumn{5}{|c|}{ As Cathode } \\
\hline Bamboo charcoal & $\begin{array}{l}\text { Carbonization at } \\
900{ }^{\circ} \mathrm{C} \text { under } \mathrm{N}_{2} \\
\text { atmosphere } \\
\text { followed by heating } \\
\text { at } 350^{\circ} \mathrm{C} \text { under air } \\
\text { atmosphere for } 2 \mathrm{~h}\end{array}$ & $\begin{array}{l}\text { Porous structure of the bamboo derived } \\
\text { cathode provides possible channels for } \\
\text { oxygen supply and proton transport. }\end{array}$ & $40.4 \mathrm{Wm}^{-3}$ & [40] \\
\hline Corn cob & $650^{\circ} \mathrm{C}$ for $2 \mathrm{~h}$ & $\begin{array}{l}\text { Higher contents of graphitic and } \\
\text { pyridinic nitrogen accelerate } \\
\text { electron transfer. }\end{array}$ & $458.8 \mathrm{mWm}^{-3}$ & [41] \\
\hline Balsa wood biochar & $800^{\circ} \mathrm{C}$ for $1 \mathrm{~h}$ & $\begin{array}{l}\text { Biochar can be used directly without } \\
\text { using the binders and catalysts. }\end{array}$ & $72 \mathrm{mWm}^{-2}$ & [42] \\
\hline Water hyacinth & $900{ }^{\circ} \mathrm{C}$ for $2 \mathrm{~h}$ & Capable of transferring electrons & $24.7 \mathrm{mWm}^{-2}$ & [43] \\
\hline Eggplant & $\begin{array}{l}\text { Pre-treated with } \\
\mathrm{K}_{3}\left[\mathrm{Fe}\left(\mathrm{C}_{2} \mathrm{O}_{4}\right)_{3}\right] \text { and } \\
\text { pyrolyzed at } 800{ }^{\circ} \mathrm{C} \\
\quad \text { for } 1 \mathrm{~h}\end{array}$ & $\begin{array}{c}\text { Possesses hierarchical porous structure } \\
\text { with a large specific surface area and } \\
\text { high graphitization degree }\end{array}$ & $667 \mathrm{mWm}^{-2}$ & {$[44]$} \\
\hline \multicolumn{5}{|c|}{ (b) } \\
\hline Biomass & Synthesis & Comment & Productivity & References \\
\hline Corncob & $\begin{array}{l}\text { Corncob particles } \\
\text { mixed with } \\
\text { melamine heated at } \\
121^{\circ} \mathrm{C} \text { for } 2 \mathrm{~h} \text {. } \\
\text { Material soaked } \\
\text { with } \mathrm{ZnCl}_{2} \text { and } \\
\text { pyrolyzed at } 700{ }^{\circ} \mathrm{C} \\
\text { for } 3 \mathrm{~h}\end{array}$ & $\begin{array}{c}\text { Fabricated biochar promoted the growth } \\
\text { of dominant bacteria and the electron } \\
\text { transfer rate. }\end{array}$ & $230 \mathrm{~mL} \mathrm{~g}^{-1}$ & [45] \\
\hline Cornstalk & $\begin{array}{l}\text { Pyrolyzed at } 600{ }^{\circ} \mathrm{C} \\
\text { for } 2 \mathrm{~h}\end{array}$ & $\begin{array}{l}\text { Biochar promotes cellulolytic enzymes } \\
\text { activity and leads to increased substrate } \\
\text { conversion into hydrogen. }\end{array}$ & $286.1 \mathrm{~mL} \mathrm{~g}^{-1}$ & [46] \\
\hline Sewage sludge & $\begin{array}{l}\text { Pyrolyzed at } 600^{\circ} \mathrm{C} \\
\text { for } 3 \mathrm{~h}\end{array}$ & $\begin{array}{l}\text { Phosphate-laden biochar used with Ca- } \\
\text { and Mg-saturated resin. Both facilitated } \\
\text { substrate degradation and reduces the } \\
\text { lag phase. }\end{array}$ & $197 \mathrm{~mL} \mathrm{~g}^{-1}$ & [47] \\
\hline Timber sawdust & $\begin{array}{l}\text { Calcinised at } 500^{\circ} \mathrm{C} \\
\text { for } 2 \mathrm{~h}\end{array}$ & $\begin{array}{l}\text { Biochar along with Fe acts } \\
\text { synergistically and results in enhancing } \\
\text { the growth and activity of microbes and } \\
\text { the utilization of substrate. }\end{array}$ & $50.6 \mathrm{~mL} \mathrm{~g}^{-1}$ & [48] \\
\hline Woody biomass & $\begin{array}{l}\text { Pyrolysis at } \\
400-500{ }^{\circ} \mathrm{C}\end{array}$ & $\begin{array}{l}\text { Co-culture of Enterobacter aerogenes and } \\
\text { E. coli was used. Biochar mitigates } \\
\text { ammonia inhibitory effect and facilitates } \\
\text { biofilm formation for efficient } \\
\text { colonization and reduces the lag phase. }\end{array}$ & $96.6 \mathrm{~mL} \mathrm{~g}^{-1}$ & [49] \\
\hline
\end{tabular}


Table 1. Cont.

(a)

\begin{tabular}{|c|c|c|c|c|}
\hline \multicolumn{5}{|c|}{ As Anode } \\
\hline Biomass & Preparation & Comments & Power Density & References \\
\hline \multicolumn{5}{|c|}{ (c) } \\
\hline Biomass & Oil & Catalyst Preparation & Yield (\%) & References \\
\hline Peanut shell & Algal oil & $\begin{array}{l}400{ }^{\circ} \mathrm{C} \text { for } 1 \mathrm{~h} \text { followed by } \\
\mathrm{H}_{2} \mathrm{SO}_{4} \text { treatment }\end{array}$ & 94.9 & [50] \\
\hline Brown algae & Waste cooking oil & $\begin{array}{c}900{ }^{\circ} \mathrm{C} \text { for } 4 \mathrm{~h} \text {, calcified with } \mathrm{CaO} \text { and } \\
\mathrm{K}_{2} \mathrm{CO}_{3} \text { at } 500{ }^{\circ} \mathrm{C} \text { for } 3 \mathrm{~h}\end{array}$ & 98.8 & [51] \\
\hline Sludge biochar & Palm oil & $\begin{array}{c}800{ }^{\circ} \mathrm{C} \text { for } 30 \text { min calcined with } \mathrm{CaO} \text { at } \\
700^{\circ} \mathrm{C}\end{array}$ & 93.7 & [52] \\
\hline Sugarcane bagasse & Palm oil & $\begin{array}{c}400{ }^{\circ} \mathrm{C} \text { for } 2 \mathrm{~h} \text {, sulfonated with } \mathrm{ClSO}_{3} \mathrm{H} \\
\text { at } 300^{\circ} \mathrm{C} \text { for } 5 \mathrm{~h}\end{array}$ & 98.6 & [53] \\
\hline Cork biochar & Waste cooking oil & $\begin{array}{c}600{ }^{\circ} \mathrm{C} \text { for } 2 \mathrm{~h} \text { and sulphonated with } \\
\mathrm{H}_{2} \mathrm{SO}_{4} \text { at } 100^{\circ} \mathrm{C} \text { for } 10 \mathrm{~h}\end{array}$ & 98 & [54] \\
\hline
\end{tabular}

In recent times, bioinspired carbonaceous materials, viz. graphene, biochar, carbon fibers, carbon nanotubes, etc., are gaining much consideration owing to their biocompatible nature for biofilm formation and microbial growth along with high surface area and conductivity. Here, nano-biochar is the renewable carbon-based material produced even by waste-organic materials for electrode production. Various biomass sources have been examined for anode/cathode preparation for efficient biofilm formation, and the properties are further dependent on several factors, i.e., pore size, available surface area, and surface properties. The pyrolyzed carbonaceous heteroatoms function as a natural dopant, delivering admirable electrical conductivity. In addition to the generation of bio-electricity, MFC is also utilized for wastewater treatment and produces low amounts of sludge compared to the traditional anaerobic digestion techniques [31]. For the cathodic performance of the carbonaceous materials, the surface area alone is a weak indicator as the existence of increased acidic functional groups regulates the oxygen reduction capability of the cathode [1].

\subsection{Nano-Biochar for Hydrogen Production}

Nano-biochar has also been utilized for biohydrogen production via three different processes, namely water splitting, methane steam reforming and anaerobic digestion. A brief discussion regarding all the mentioned technologies is presented in the following section. Table 1(b) summarizes the utilization of nano-biochar for hydrogen generation.

\subsubsection{Nano-Biochar for Water Splitting}

Water splitting using numerous electro-catalysts of the noble metals and their oxides, e.g., $\mathrm{RuO}_{2}$ and $\mathrm{IrO}_{2}$, is the cleanest way of hydrogen production, however, the process is still inefficient owing to the high catalyst cost, instability in the alkaline environment, and overpotential of the $\mathrm{H}_{2}$ evolution reaction (HER) and $\mathrm{O}_{2}$ evolution reaction (OER) at the cathode and anode, respectively $[55,56]$. Therefore, bio-inspired carbonaceous materials are nowadays being explored as electrocatalysts due to their cost-efficient electrical conductivity [1]. Further, to reduce the overpotential and enhance the hydrogen generation ability, transition metals can be doped on carbonaceous materials to create more active sites for rapid electron transference [57]. In addition, the presence of alkali and alkaline earth metals assists in the carbon and porosity activation through the ionic migration effect at the high temperature. Recently, biochar-derived molybdenum carbide $\left(\mathrm{Mo}_{2} \mathrm{C}\right)$ has gained consideration owing to its Pt-similar stability and structure. Still, the HER efficacy of $\mathrm{Mo}_{2} \mathrm{C}$ 
electro-catalysts is less because it lacks exposed catalytic sites along with strong $\mathrm{Mo}-\mathrm{H}$ bonding $[1,56]$.

\subsubsection{Nano-Biochar for Methane Steam Reforming}

Methane can be generated via the anaerobic digestion of the organic wastes that present the maximum hydrogen to carbon ratio (4:1). Further, the thermo-catalytic decomposition of methane leads to the generation of pure hydrogen at a very high temperature $\left(1200^{\circ} \mathrm{C}\right)$ for the conversion reaction initialization. Thus, metallic catalysts $(\mathrm{Ni}, \mathrm{Fe}, \mathrm{Cu}$, etc.) are involved in enhancing the methane conversion at a lower temperature. However, these metallic catalysts lose their activity very fast. In addition, the presence of sulphur in the natural atmosphere is further harmful to the catalysts [1]. Carbon materials have greater stability and are resilient to sulphur content. Carbonaceous materials doped with metals in trace amount present enhanced activity owing to the generation of high energy active sites that attract the methane, further helping in the enhanced methane conversion to hydrogen. Nowadays, the nano-biochar prepared from bio-solids recovered from wastewater treatment plants is utilized for the methane steam reforming process resulting in $65 \%$ conversion [58].

\subsubsection{Nano-Biochar for Biogas Production}

Organic bio-waste management using an AD process leads to bioenergy generation. It was stated that the nano-biochar addition during the $\mathrm{AD}$ enhances the hydrogen yield with a minimal lag phase. It is predicted that the nano-biochar enables biofilm formation and $\mathrm{pH}$ stabilization, and enhances the generation of volatile fatty acids (VFAs) [59]. Further, the minerals existing in the nano-biochar are responsible for providing supplements for microbial metabolism and enzyme synthesis and activity. Biochar-derived from pine dust during the two-phase $\mathrm{AD}$ of aqueous carbohydrates resulted in enhanced methane and hydrogen yield by $10 \%$ and $31 \%$, respectively [60]. Furthermore, microbes may acclimatize to numerous inhibitors, but that might be time-consuming and affect cellular productivity. The nano-biochar aided AD process tends to remove the inhibitors and reduce the toxicity, thus improving in hydrogen production [1].

\subsection{Nano-Biochar for Biodiesel Production}

The occurrence of long carbon chain $\left(\mathrm{C}_{14}-\mathrm{C}_{20}\right)$ fatty acids has gained the attention for biodiesel production for the present engines owing to their high energy densities. The transesterified oils from various renewable resources produce biodiesel [61]. During the transesterification process, catalysts playing a major role are further categorized into two types, i.e., homogenous and heterogeneous catalysts. Heterogeneous catalysts can simultaneously perform transesterification and esterification reactions. Table 1(c) lists examples of the utilization of nano-biochar as catalyst for biodiesel production.

Biochar, defined as a heterogeneous catalyst, has clearly shown its potential for biodiesel production. Transesterification reactions were carried out in the presence of nano-biochar that was altered via either acid/alkali as the catalyst. The porosity of the nano-biochar permits the reactants easy access to active sites to enable the transesterification reaction [1]. In addition, the hydrophobic surface of nano-biochar assists in the water elimination during the conversion reaction. The biochar acid-modified via the sulfonation process contains $-\mathrm{SO}_{3} \mathrm{H}$ groups on the biochar surface and further acts as the catalyst, while the alkali-modified biochar has basic sites primarily consisting of calcium, potassium, or sodium oxides that are produced during the calcination of the minerals present in the organic substrate [51-53]. During the transesterification reaction, the alcohols and lipids utilize the porous structure to accelerate the reactants' collision frequency at ambient pressure. 


\section{Nano-Biochar for Anaerobic Digestion}

Depending on the conditions, the nano-biochar characteristics can be enhanced for application. Nano-biochar characteristics such as porosity, specific surface area (SSA), cation exchange capacity, electrical conductivity, redox potential, $\mathrm{pH}$, and functional groups play an essential role during the AD process [62].

\subsection{Porosity}

Nano-biochar porosity is a crucial factor in recognizing the probable association with microbes during AD. The biochar pore size acts as microhabitats for microbes to flourish [63]. The typical microbial size in AD is $0.3-13 \mu \mathrm{m}$ for bacteria/archaea, 2-80 $\mu \mathrm{m}$ for fungus, and 7-30 $\mu \mathrm{m}$ for protozoa [56]. In addition, the porosity of biochar enables the formation of biofilm, acting as a protection for the amelioration of selective and effective microbes participating in the AD system in an acidic environment [64]. The addition of nano-biochar selectively enhances the numerous bacterial species in the AD system. Most research has documented Methanolinea, Methanobacterium, and Methanosarcina sp. in anaerobic digester supplemented with biochar. Numerous studies reported the spatial dispersion of archaea and bacteria by separating the sludge into several portions [65]. The spatial dispersal of methanogens in the biochar pores is due to their diverse size and morphology [66].

\subsection{Specific Surface Area}

The SSA of nano-biochar is one of the crucial parameters for environmental pollutants adsorption [63]. The nano-biochar capacity to remove $\mathrm{CO}_{2}, \mathrm{H}_{2} \mathrm{~S}$, etc. in a biogas fermenter was studied by Sethupathi et al. [67]. They observed values of $0.208 \mathrm{mmol} \mathrm{g}^{-1}$ and $0.126 \mathrm{mmol} \mathrm{g}^{-1}$ for $\mathrm{CO}_{2}$ and $\mathrm{H}_{2} \mathrm{~S}$, respectively. The adsorption of $\mathrm{CO}_{2}$ by biochar (hickory wood and bagasse), the involvement of high SSA and $\mathrm{N}_{2}$ group of biochar for removal was reported by Creamer et al. [68]. The pore size of biochar $(0.5-0.8 \mathrm{~nm})$ and enhanced SSA were reported for sequestration of $\mathrm{CO}_{2}$ [69], whereas the group I-II A metals and primary functional groups present on the surface play an essential role [70].

\subsection{Cation Exchange Capacity}

The concentration of ammonium $\left(\mathrm{NH}_{4}{ }^{+}\right)$and $\mathrm{NH}_{3}$ are sustained under an optimized threshold for an AD process; it helps in buffer capacity for improved growth of bacteria, whereas the excess amount of total $\mathrm{NH}_{3} /$ free $\mathrm{NH}_{3}-\mathrm{N}$ (TAN/FAN) can cause AD catastrophe [71]. It was observed that TAN content $\left(1.7\right.$ and $\left.14 \mathrm{~g} \mathrm{~L}^{-1}\right)$ decreased the generation of $\mathrm{CH}_{4}$ by $50 \%$ and free ammonium nitrogen (FAN) (150 and $1200 \mathrm{mg} \mathrm{L}^{-1}$ ) content significantly influences the growth of methanogens [71,72]. Biochar could significantly improve the inhibition of $\mathrm{NH}_{3}$ and increase $\mathrm{CH}_{4}$ generation by decreasing the microbial lag phase owing to its strong cation exchange capacity (CEC). Shen et al. [73] reported the positive role of biochar in AD of sewage sludge. Su et al. [74] stated that biochar alleviated the $\mathrm{NH}_{3}-\mathrm{N}\left(\sim 1500 \mathrm{mg} \mathrm{L}^{-1}\right)$ in food waste AD. Likewise, Lü et al. [66] stated that enhanced $\mathrm{NH}_{4}+$ content (up to $7 \mathrm{~g}-\mathrm{N} \mathrm{L}^{-1}$ ) could be repressed by biochar supplementation during AD. The mechanisms include microbial immobilization, physicochemical adsorption capacity, CEC, surface functional groups (SFG), and DIET advancement [73-75].

\subsection{Electrical Conductivity}

The microbial syntrophic interaction depends on the electrical conductivity (EC) [63]. However, the EC of nano-biochar is insignificant in contrast to the EC of digestate, which is based on the microbes' metabolism and composition [76]. Nano-biochars' ability to enhance DIET is equal to that of granular activated carbon, despite the lower biochar EC [77] although some nano-biochar has high EC (e.g., basswood nano-biochar) [78]. Barua and Dhar [79] reported increased EC $\left(0.2-36.7 \mu \mathrm{S} \mathrm{cm}^{-1}\right)$ in numerous microbes due to DIET. Martins et al. [76] proposed that humic substances could act as electron transport media to accelerate DIET. 


\section{5. $p H$}

The $\mathrm{pH}$ influences the conductivity of nano-biochar and associated microbes in AD [80]. Due to the ash concentration and acidic functional groups volatilization, the $\mathrm{pH}$ values of nano-biochar are alkaline. The rise in biochar's pyrolysis temperature and $\mathrm{pH}$ value frequently surges [81]. In addition, the nano-biochar has redox ability, i.e., it can accept or donate the electrons. Further, the presence of aromatics and phenolic groups also aids in the electron transfer [3,82]. Nano-biochar increases the AD alkalinity (minimum $\mathrm{pH} \geq 6$ ), enhancing the microbial activity for fast $\mathrm{CH}_{4}$ generation and adaptability to initial the loading shock [83]. Nano-biochar significantly facilitates the methanogenesis stage under acidic conditions ( $\mathrm{pH}$ 5.3), improving the operating conditions with increased organic loading and total solids [81]. Hence, with the addition of nano-biochar, a continuous AD process can function with a shorter hydraulic retention time and operate under an extra organic loading rate.

\subsection{Surface Functional Groups}

The nano-biochar surface consists of various functional groups such as $-\mathrm{OH}, \mathrm{C}-\mathrm{O}$, $-\mathrm{COOH}, \mathrm{CO},-\mathrm{NH}_{\mathrm{x}}$, etc. which assist in nutrient retaining and pollutant removal [84]. Nano-biochar displayed significant outcomes in the adsorption of $\mathrm{NH}_{3}$ from wastewater and digestate. The nano-biochar's porosity and high SSA aid in the physisorption [85]. However, in some studies, it is not a predominant parameter in adsorption of $\mathrm{NH}_{4}+[86,87]$. For instance, amid $\mathrm{NH}_{4}+$ and nano-biochar acidic functional groups, ion exchange occurs [85], and CEC plays a significant role in enhancing the adsorption capacity of biochar's towards $\mathrm{NH}_{4}+$ [88]. Sahota et al. [89] employed biochar to remove $\mathrm{H}_{2} \mathrm{~S}$ from biogas and attained $84.2 \%$ elimination efficacy. Likewise, Kanjanarong et al. [90] accomplished $98 \% \mathrm{H}_{2} \mathrm{~S}$ elimination efficacy via biochar and concluded that $\mathrm{COOH}$ and $\mathrm{OH}$ groups are responsible for the observed $\mathrm{H}_{2} \mathrm{~S}$ adsorption.

\subsection{Redox Potential}

The nano-biochar redox properties are critical during AD. The biochar redox properties are due to its SFG, free radicals, and metals (M) and metal oxides (MO) [91]. For example, the electron-donating capacity is due to the presence of phenolic $\mathrm{C}-\mathrm{OH}$ fractions, while electron-accepting ability is due to quinoid $\mathrm{C}=\mathrm{O}$ fractions [92]. An oxidation process can enhance nano-biochar SFG [93]. Hitherto, the oxidation process should be appropriate to familiarize with novel functioning, but not too robust to trigger the alteration to the $\mathrm{COOH}$ group (redox-inactive) or even to eliminate $\mathrm{CO}_{2}$ [91]. Free radicals influence the nanobiochar redox propensity, such as aryl radicals or as semi-quinoid radicals [94]. Concerning the nano-biochar's inorganic constituent, Fe and Mn oxides (redox-active metals) usually exist in the biomass and diverse oxidation states act as electron acceptors and donors [95].

\section{Roles and Mechanisms of Nano-Biochar in Anaerobic Digestion}

The intrinsic characteristic of nano-biochar boosts biofilm microbial development (methanogens colonization) and adsorption of $\mathrm{NH}_{3}$ and acetate (inhibitors) [96]. AD process aids in the development of a defensive layer for microbes that enhances $\mathrm{CH}_{4}$ generation. Nano-biochar also stabilizes the microbe's nutrient access and eliminates volatile fatty acids and $\mathrm{NH}_{3}$ [97]. Figure 3 presents a brief schematic of the anaerobic digestion system aided with the nano-biochar for enhanced biogas production. 


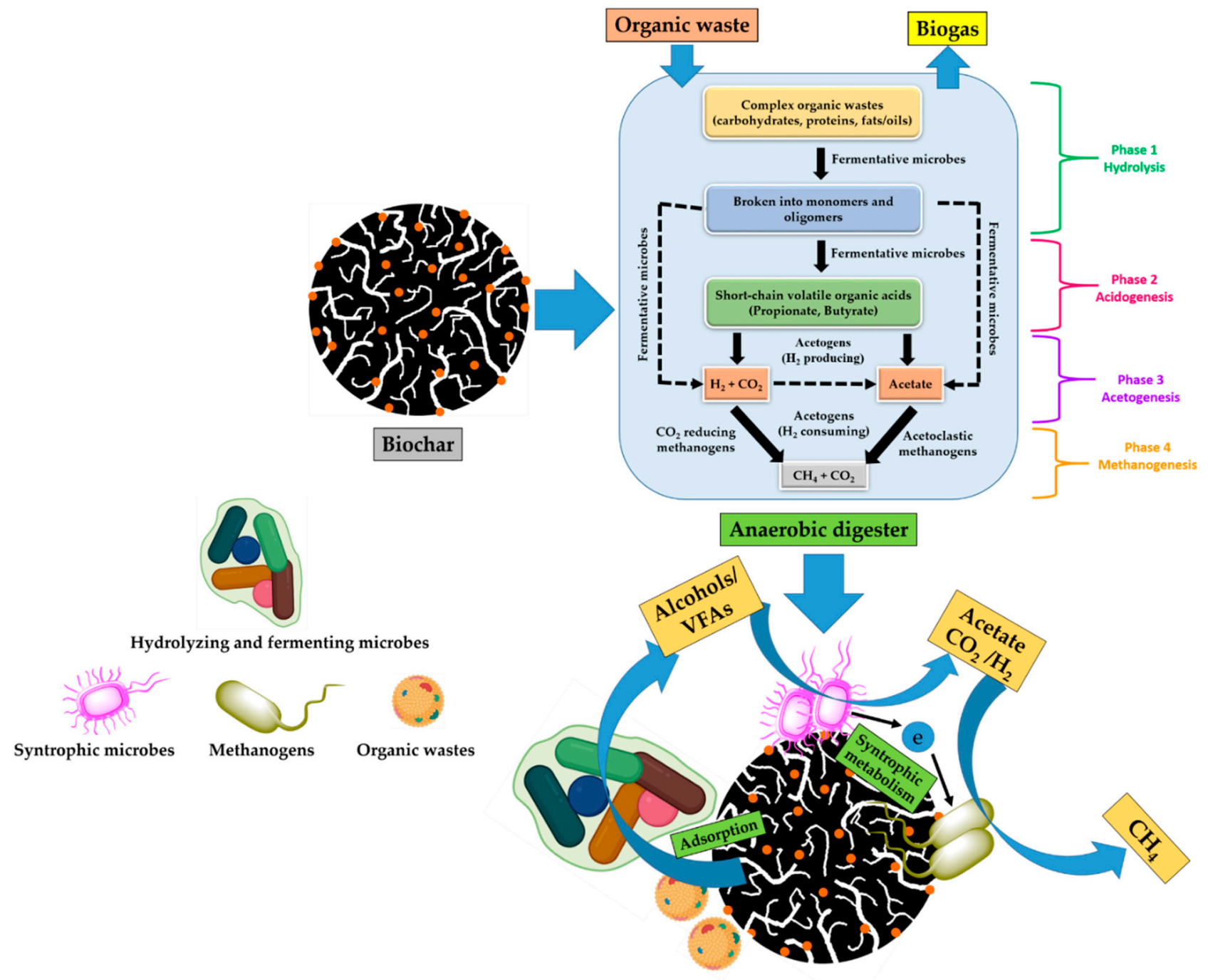

Figure 3. Anaerobic digestion system aided with the nano-biochar for enhanced biogas production.

\subsection{Improving the Process Stability}

AD stability is crucial for a continuous conversion of biowaste, which can be enhanced by nano-biochar usage via $\mathrm{NH}_{3}-\mathrm{N}$ improvement [75]. Nano-biochar improves the methanogenic microbes in the presence of acid and $\mathrm{NH}_{3}$ impediment, which ultimately helps in nitrogen-rich substrate degradation and reduces $\mathrm{NH}_{3}$ inhibition, thereby improving AD performance [97]. The nano-biochar addition decreases the AD major inhibitor (free $\mathrm{NH}_{3}$ ) by $10.5 \%$ and encourages the methanogenesis process under an acidic environment [98]. Nano-biochar significantly increases the AD alkalinity $(\mathrm{pH} \geq 6$ ), therefore supporting the acclimatization of microbes and enriching their activity in the presence of organic loading for more substantial production of $\mathrm{CH}_{4}[99,100]$. However, studies reported the toxic effects of the high biochar concentration ( $4.5 \mathrm{~g}$ biochar/g of dry sludge), such as decreased microbial activity [98]. Therefore, optimizing the nano-biochar amount and incessant monitoring are crucial to curtailing the adverse effects on the metabolism of microbes and the intermediate metabolite generation.

\subsection{Accelerating the Process Rate}

AD system process rates can be efficiently enhanced with the addition of nano-biochar. Shanmugam et al. [101] observed a decrease $(24 \mathrm{~h})$ in the methanogenic microbe lag phase when algal-derived biochar was used for wastewater AD. Earlier results supported this outcome that the microbial lag phase duration was inversely proportional to the 
biochar to substrate ratio. The 7.5 days lag phase was the optimized ratio [102]. Likewise, Sunyoto et al. [60] reported 21.4-35.7\% and 41-45\% decreases in the lag phase of $\mathrm{H}_{2}$ and $\mathrm{CH}_{4}$ reactors on biochar, respectively. The magnetic biochar addition during methanogenesis entirely avoided the lag phase or decreased it by $0.9-1.83$ days [103,104]. Furthermore, Wang et al. [105] reported a reduction of lag phase from 4.7 to 1.8-3.9 days during codigestion of food waste and sewage sludge on biochar application. The daily production of $\mathrm{CH}_{4}$ was improved by $136 \%$ after the amendment of biochar (wood-pellet-derived) during the AD process [97].

\subsection{Buffering Potency and Alkalinity}

The efficiency of AD systems mainly relies on the $\mathrm{pH}$ value, where a slight decline in the $\mathrm{pH}$ of the solution remarkably hinders microbial growth and functioning [106]. Food wastes with low $\mathrm{C}: \mathrm{N}$ ratio and enhanced biodegradability result in a rapid acidification rate during AD. During the acidogenesis phase, the fast growth of acidogenic bacteria will affect the activity of methanogen's and result in the VFAs accumulation [107]. Fotidis et al. [108] established that the aforementioned state might arise during high organic load with easily biodegradable biomass. As the AD system has an extended recovery period from gathered VFAs, amendment of nano-biochar can aid in a fast and simple process to hasten the recovery of acidified anaerobic reactors [81]. The buffering capacity and availability of nutrients are significantly influenced by nano-biochar during the co-digestion system [105,109]. However, there are a few opposing results regarding the biochar application in the AD process. Luo et al. [64] proposed that before $\mathrm{CH}_{4}$ generation, acid inhibition might happen during synthetic wastewater $\mathrm{AD}$, and nano-biochar cannot significantly upsurge the $\mathrm{pH}$ buffering capacity. A decrease in $\mathrm{pH}$ value (5.0 to 3.0) owing to VFAs accretion even after nano-biochar addition during AD was observed by Sunyoto et al. [60]. Thus, there is no inference about the nano-biochar $\mathrm{pH}$ buffering capacity during the AD, which is based on the nano-biochar physicochemical properties and flexible operational parameters.

\subsection{Inhibitors Adsorption}

One of the key advantages that nano-biochar offers to raise AD effectiveness is the adsorption of inhibitors. During the adsorption process, the biochar aromatic structures enable $\pi-\pi$ interaction due to $\mathrm{OH}$ and $\mathrm{COOH}$ groups [90]. The adsorption of VFAs by nano-biochar and alleviation of acid surges the $\mathrm{CH}_{4}$ yield [101]. The study showed direct proportionality amid $\mathrm{NH}_{4}{ }^{+}-\mathrm{N}$ adsorption and hydrochar SSA [105]. Linville et al. [110] assessed biochar derived from the walnut shell and found significant removal of $\mathrm{CO}_{2}$ by coarser (51\%) and smaller biochar (61\%) in the food waste AD. In the two-stage wasteactivated sludge AD by pine wood and corn stover biochar, $\mathrm{CH}_{4}$ contents of $81-88.6 \%$ in corn stover and $72.1-76.6 \%$ in pinewood biochar were observed, respectively [73]. The $\mathrm{CO}_{2}$ was sequestered into carbonate/bicarbonate by base cations released by biochar $[96,111]$.

\subsection{Enriched Microbial Functionality}

Nano-biochar encourages the extracellular polymeric substance (EPS) secretion from microbes during the formation of biofilm, thereby increasing the adhesion of microbes on the surface of nano-biochar [112]. It is a cost-effective and easy method to evade fast sludge granulation and decrease the methanogens loss during AD. Sun et al. [113] observed the microbial richness in the incidence of biochar carriers. Dang et al. [114] found that Enterococcus and Sporanaerobacter capacity was improved during biochar addition, which aids in fermentable substrates breakdown for electron transfer to Methanosarcina. In addition, the biological interaction between Methanosaetaceae and Methanosarcinales and biochar efficiently decreases the lag time [66]. Wang et al. [115] found that the hydrochar content is directly proportional to the attachment of methanogenic bacteria. Similarly, in the presence of hydrochar, Methanosaeta (acetoclastic methanogen) enrichment was observed [81]. Henceforth, $\mathrm{CH}_{4}$ generation from VFAs is enhanced by immobilization 
of methanogens by hydrochar amendment [116]. Furthermore, biochar increases biofilm formation and functional microbial enrichment, thus, improving the AD process [80].

\subsection{Electron Transfer Mechanism}

The earlier investigations reported the importance of nano-biochar and its electron transfer amid archaea and anaerobic bacteria. AD system efficacy mainly depends upon the syntrophic interactions amid bacteria and methanogens, which help electrons fulfill their energy requirements [76]. Figure 4 gives an overview of proposed electron transfer mechanisms between oxidizing bacteria and methanogens. It is carried out in various ways: DIET via a conductive medium (e.g., granular activated carbon, magnetite, carbon cloth, nanobiochar) [117], membrane-bound transporter proteins [76], electric conductive pili [79], and indirect interspecies electron transfer (IIET) through insoluble (humic compounds) [118] and soluble (acetate, formate) substances [119,120]. In IIET, formate and hydrogen act as electron transport between methanogens and syntrophic-generating bacteria [76]. The microbial metabolite exchange is governed by Fick's Law, occurring via diffusion. Thus, after the cell accumulation is attained, the interspecies hydrogen transfer rate is raised by anaerobic bacteria and methanogenic archaea form the compressed structures [121].

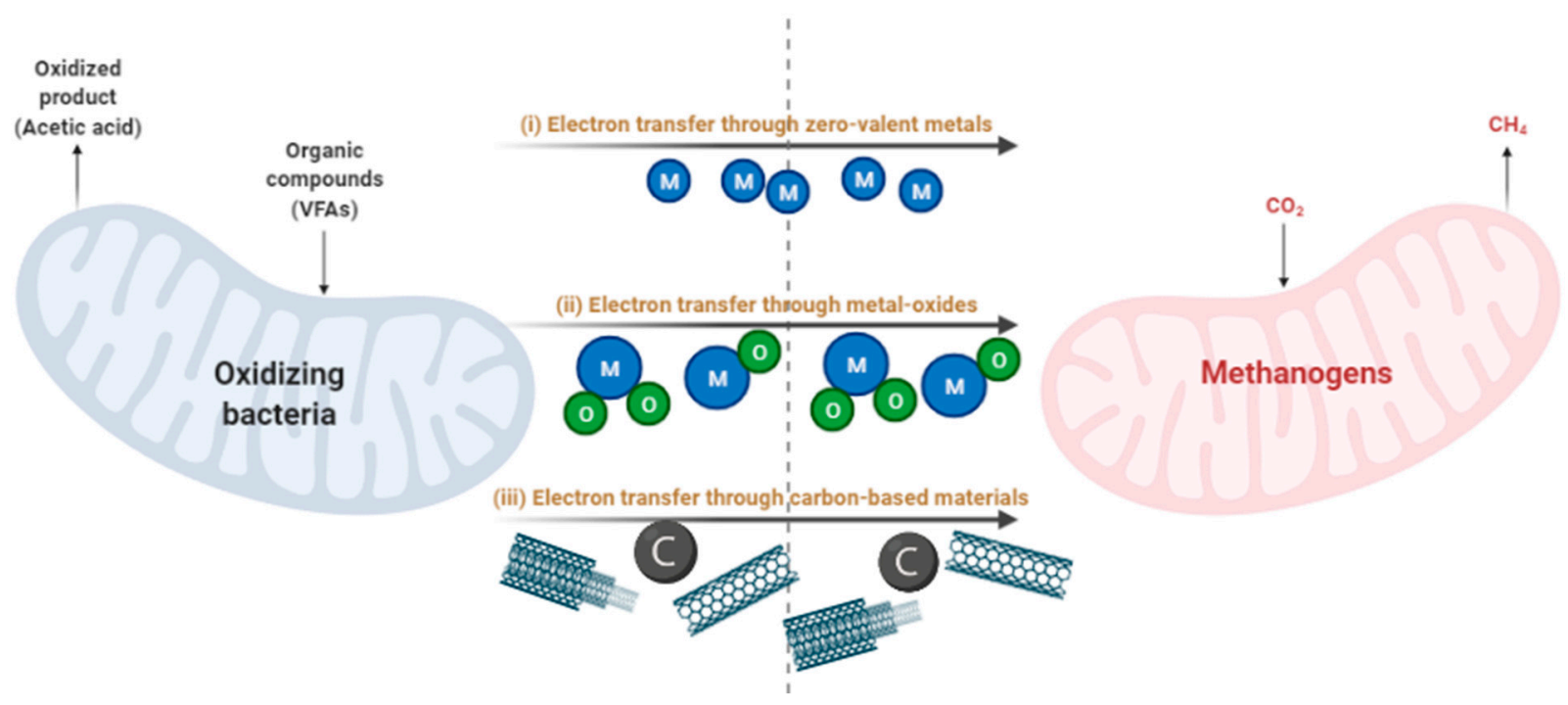

Figure 4. Application of conductive nanoparticles for electron transfer between oxidizing bacteria and methanogens via (i) zero-valent metals; (ii) metal oxides, and (iii) carbon-based materials.

During $\mathrm{CH}_{4}$ production, IIET and diffusion of soluble metabolites are bottlenecked by decelerating the electron transference and energy transfer rate [77,122]. DIET does not entail the electron transport intercession for generating an electric current amid electronaccepting and donating microbes [76]. DIET was more precise and rapid than IIET [122]. Martínez et al. [123] reported that co-culture enhances $\mathrm{CH}_{4}$ generation, for instance, enrichment of homoacetogenic bacteria such as Eubacterium, Clostridium, and Syntrophomonas. In synthetic wastewater AD, Methanosaeta and Geobacter enrichment on biochar in the presence of propionate and butyrate were reported [65]. During conductive biochar amendment, DIET was able to eliminate butyrate and propionate and establish interspecific electron shuttle by Smithella and Syntrophomonas richness.

\section{Kinetics Involved during the AD Process}

The kinetic study of AD system is the most important way to evaluate the performance of the reactor for biogas production, mechanism of metabolic pathways, biomass degradation, and the monitoring of the growth rate of microorganisms [124,125]. Based on increasing $\mathrm{CH}_{4}$ production after the biochemical $\mathrm{CH}_{4}$ production (BMP assay), the 
bio-kinetics parameters such as $\mathrm{CH}_{4}$ generation potential, maximum rate, and its period of lag phase are evaluated to utilize the three diverse kinetics models. In general, the first-order kinetic model such as Chen and Hashimoto model [126], Cone model, and modified Gompertz model [124,127] were applied to mimic the kinetic patterns of biogas production in different condition. The first-order kinetic model and modified Gompertz model are used for biomass degradation rate and biomethane production rate in batch and continuous reactors [128,129]. The obtained cumulative biomethane productivity results through the modified Gompertz kinetic model (fitting error 0.7-13.7\%) were more authentic than first-order kinetic (fitting error 9.2-37.1\%) for organic waste material [129]. In addition, the quality of products depends on the type of substrates responsible for acidogenesis, acetoclastic, and methanogenesis by microorganisms in the digestion system. Here, the modified Gompertz and logistic function obey the sigmoidal process that correlates the methanogenic archaea growth with the $\mathrm{CH}_{4}$ generation in an anaerobic reactor. In contrast, the transference function follows the first-order curve to correlate the $\mathrm{CH}_{4}$ generation with the microbial activity [130].

$$
\begin{gathered}
\text { Modified Gompertz Model; } y=M \cdot \exp \left\{-\exp \left[\frac{R_{m} e}{M}(\lambda-t)+1\right]\right\} \\
\text { Logistic Function Model; } y=\frac{M}{1+\exp \left(\frac{4 R_{m}(\lambda-t)}{M}+2\right)} \\
\text { Transference Function Model; } y=M\left\{1-\exp \left(-\frac{R_{m}(t-\lambda)}{M}\right)\right.
\end{gathered}
$$

where $y$ is the accumulated $\mathrm{CH}_{4}(\mathrm{~mL})$ at time $t(\mathrm{~h}), M, R_{m}, \lambda$, and $e$ are the potential $\mathrm{CH}_{4}$ generation ( $\mathrm{mL} \mathrm{CH}_{4} \mathrm{~g}^{-1}$ ), maximum rate of $\mathrm{CH}_{4}$ production $\left(\mathrm{mL} \mathrm{CH}_{4} \mathrm{~g}^{-1} \mathrm{~h}^{-1}\right)$, lag phase time $(\mathrm{h})$, and base and constant of the natural logarithms, respectively.

Kinetic models can be divided into structured (complex degradation and fermentation mechanism analysis) and unstructured (substrate consumption, growth rate along with production evaluation) models. The structured models are used for unsteady-state balance, while the unstructured models are used to assess steady-state balance conditions during the anaerobic process $[127,129]$. Some researchers have reported that the maximum growth rate value in the exponential phase is minimum at low substrate concentration. In the case of acetate inhibition at a higher substrate concentration, Andrew's kinetic models for AD (Equations (2) and (3)) that express the acetolactic methanogenesis stage can be used [124,131].

To examine the theoretical $\mathrm{CH}_{4}$ yield (TMY) from the organic wastes on the basis of the elemental contents of the substrates, the following equations are given (Buswell formula [132]):

$$
\begin{aligned}
\mathrm{C}_{n} \mathrm{H}_{a} \mathrm{O}_{b} \mathrm{~N}_{c}+(n \quad & \left.-\frac{a}{4}-\frac{b}{2}+\frac{3 c}{4}\right) \mathrm{H}_{2} \mathrm{O} \\
= & \left(\frac{n}{2}+\frac{a}{8}-\frac{b}{4}-\frac{3 c}{8}\right) \mathrm{CH}_{4}+\left(\frac{n}{2}-\frac{a}{8}+\frac{b}{4}+\frac{3 c}{8}\right) \mathrm{CO}_{2}+c \mathrm{NH}_{3} \\
& \operatorname{TMY}\left(\frac{\mathrm{mLCH}_{4}}{g V S}\right)=\frac{(22.4)(1000)\left(\frac{n}{2}+\frac{a}{8}-\frac{b}{4}-\frac{3 c}{8}\right)}{12 n+a+16 b+14 c}
\end{aligned}
$$

In addition, the anaerobic biodegradability of the organic feedstocks can be evaluated by dividing the experimental $\mathrm{CH}_{4}$ yield by theoretical $\mathrm{CH}_{4}$ yield. Furthermore, the surfacerelated models (Contois kinetics) for anaerobic digestion have not been much developed. Several researchers reported hydrolysis as a first-order kinetic model reaction that depends on various substrates and particle size. These limitations of pertinent simulation in the biogas generation mainly rely on the data availability and accuracy of the process. The methanogenesis effect with the kinetic limitation of the substrate is used in diverse kinds of inhibition models in the AD system. AD process is considered as $\mathrm{H}_{2}$ and $\mathrm{H}_{2} \mathrm{~S}$ inhibition with 
the ionic balance and $\mathrm{pH}$ level in the biogas process system. The standard $\mathrm{CH}_{4}$ formation rate is based on the un-dissociated hydrogen and sulphur concentration. Furthermore, the occurrence of oxygen is very sensitive; it breaks the degradation process in the AD system [133].

\section{Closed-Loop Integration of Biochar and Anaerobic Digestion}

The inherent complication in AD process is related to the different groups of microbes. The conventional ways such as pre-treatments (reducing the retardation rate) and cosubstrates (the balance of nutrients, very low accumulation of toxicity), do not perform well to deal with such challenges [62,134]. In this respect, several new approaches and productive concepts are required, some of which are enumerated below:

(i) a synergetic integration of different technologies and proceed in methodical ways

(ii) development of the zero liquid discharge (ZLD) through cascade system

(iii) processing biomasses in concurrence with the closed-loop integrated system

These methodical routes of advanced blueprinted bio-energetic system offer several advantages, viz. supporting maximum recycling of biomass through managing material and energy which needed from the same feedstock (low energy consumption) [135], promoting the new income of source. Therefore, it also favors the ecological environment $[136,137]$. This integrated system uses the solid biomass residue for pyrolysis, which produces nano-biochar and is used as an additive in the AD reactor to enhance bio-methane production. Further, nano-biochar can be used as an adsorbent to enrich the nutrients in the slurry, or can also be used for agriculture as a fertilizer and soil conditioner. In this process, methane gas is produced, and it can further be used to generate power and heat. Hence, this integrated closed-loop system promotes crucial techniques for producing biomass during AD [138].

Deng et al. [139] achieved 17\% yield increase of $\mathrm{CH}_{4}$ and $10 \%$ bio-oil yield increase through the integrated system of AD and pyrolysis, and obtained $26 \%$ reduction in digestate biomass from seaweed. Similarly, Sen et al. [140] reported that in a study of a closed-loop system using the additive nano-biochar, the biomethane yield could be enhanced by $7 \%$, the bio-methanation rate constant by $8.1 \%$, and the maximum methane production rate by $27.6 \%$, as well as increased alkalinity and mitigated $\mathrm{NH}_{3}$ inhibition for $\mathrm{AD}$. AD with pyrolysis favored both pyrolysis of liquor and pyrolysis of solid digestate, where nano-biochar acts as a catalyst for $\mathrm{AD}$ by supporting the mitigated $\mathrm{NH}_{3}$, buffering, and alkalinity. Therefore, an integrated system of AD with pyrolysis is a promising way for the amalgamation of biological (AD) and thermochemical processes (pyrolysis) [141].

To improve circular economics and the sustainability effect of the AD effluent, alternative methods (converting digestate to pyrogenic carbon) are required, which may be considered as a feasible pathway because nowadays nano-biochar is considered as a carbon reservoir/carbon-negative technology, that is, contributing to greenhouse gases (GHG) emission [142], due to its properties such as having a high amount of highly stable carbon, and long-term carbon segregation capacity especially in an integrated system with AD [135,137]. Monlau et al. [135] revealed that solid-digestate (containing about 30-50\% of organic carbon, on dry basis) was treated close to the pyrolysis in terms of excess amount of energy, similar to the pyrolysis nano-biochar. It was evident that the integrated system (AD \& pyrolysis) anticipated a net $42 \%$ increase in electricity production. The AD system has various limitations such as inhibition of $\mathrm{NH}_{3}$, quality of digestate, and low quality of biogas. However, by using this vigorous closed-loop integration (AD-pyrogenic carbon), more green and clean energy can be produced.

Further, the accomplishment of nano-biochar on anaerobic reactors such as acidogenesis, acetogenesis, hydrolysis, and methanogenesis is to be carried out for improving the buffering capacity and increasing acid pressure [62]. Nano-biochar is a vital way to aid in bio-shielding of archaea under acidic pressure and its reactive mechanism in AD reactors. Nano-biochar has proven its role as a stabilizer to enhance the syntrophic metabolism of VFAs and alcohol, enabling one to shorten retention times in AD [143]. 
The productivity for $\mathrm{CH}_{4}$ during bio-methanation can be improved by improving anaerobic methanogens, which are promoted through a consortium of methanosarcina and syntrophic bacteria. Selective colonization is observed and had an ammonium adsorption capacity up to $17.6 \mathrm{mg} \mathrm{g}^{-1}$ by biochar [144]. DIET has been recognized as an alternative pathway for hydrogen interspecies transfer of syntrophic electrons between Geobacter and Methanosarcina to accelerate the syntrophic metabolism of ethanol by incorporating nano viruses. After which, methanogenic electron movement can be increased due to acetic acid formation [143], amplifying methanogenesis, directing to acidogenesis-acetogenesis, supporting the minimal corrosion and eccentric colonization of methanogenesis for improvement in selective productivity.

The most interesting factor for nano-biochar use as an AD additive is its minimal complexity, low cost, and very low risk of formation of second-hand pollutants. Meanwhile, porous material biochar contains a specific molecular structure [66], which stimulates AD at advanced levels. Many researchers have reported the performance of biochar such as hydrothermal carbonization and pyrolytic biochar for their low effects on ammonia inhibition and microbial growth [63]. Some issues related to using biochar in AD are still unsolved. Thus, there is a need to model the operational procedure, evaluation via advanced techniques with references at an earlier stage. Hence, nano-biochar may be a suitable replacement for conventional approaches.

\section{Techno-Economic and Environmental Life Cycle Assessment}

The techno-economic and environmental assessment of nano-biochar application in $\mathrm{AD}$ is imperative according to the production cost, vending cost, operating cost, profits, low carbon emissions, reduced secondary pollution, and less global warming potential at the commercial level [62]. These evaluations were also performed to raise the economic feasibility of nano-biochar application in full-scale along with the long-term operation of the AD process. In addition, the characteristic properties of the nano-biochar, feed type, production conditions, etc. all play a vital role in the AD performance that is mentioned in the current section.

\subsection{Techno-Economic Analysis}

Various researchers have performed the economic assessment of nano-biochar production to determine the investment that might be further balanced via the biochar trade price $\left(470 € \mathrm{t}^{-1}\right)$ [145]. Nano-biochar yield is mostly affected via oxygen to carbon (O/C), molecular ratio during pyrolysis and the ash content. A high $\mathrm{O} / \mathrm{C}$ ratio in the feed substrate reduces the nano-biochar selectivity and enhances the formation of bio-oil, while a low ash content leads to an increase in the nano-biochar yield and decreases the bio-oil yield [62]. Adding biological and inorganic elements within the nano-biochar as additives in AD is usually carried out to increase methane production. These additions further lead to an increase in the overall production of the biochar; for instance, nutrients and enzymes add in 13-16 and 3.6-4.1 € $\mathrm{L}^{-1}$, respectively [146].

The trending circular economy model was also applied for managing the digestate produced via the AD process of the organics [147]. The researchers have followed the "back to Earth" concept to deal with the digestate produced via AD of food and municipal solid wastes. The simultaneous integrated utilization of the biochar-aided AD and further recycling the digestate for the nano-biochar synthesis is consistent with the "zero-waste" concept approach. The digestate can also be used for fuel, energy, fertilizer, and chemical production for the industries [148]. In addition, the installation cost, pre-treatment cost (covering 43\%), and hydrogen purification cost (22\%) is chiefly involved in the overall cost. The average operating cost for nano-biochar derived from woody and straw biomasses are 0.68 and $0.86 € \mathrm{~L}^{-1}$, respectively, in comparison to the additives, viz., nutrients (13$\left.16 € \mathrm{~L}^{-1}\right)$ and enzymes $\left(4.10 € \mathrm{~L}^{-1}\right)$ [121]. Traditional biochar $\left(5-25 \mathrm{~g} \mathrm{~L}^{-1}\right)$ can be utilized as an additive in the AD process and is reused many times, making the process more economically feasible and the additional gain of by-products [149]. González et al. [150] 
reported a case study of the economic feasibility of an integrated system and NPV could be calculated using the following equation:

$$
\text { Net present value }(N P V)=-T C C+\sum_{t=1}^{n} \frac{C F_{t}}{(1+r)^{t^{\prime}}}
$$

where TCC is the total capital cost of the investment for the digestion and pyrolysis plant, $C F_{t}$ is the cash flow expected at time $t$, and $r$ is the discount rate.

Nevertheless, this analysis for the cost evaluation of nano-biochar aided AD process on a large scale is still at its embryonic stage. Henceforth, many researchers have further approached the life-cycle assessment (LCA) to analyze the total input energy required for $\mathrm{CH}_{4}$ production [151].

\subsection{Life-Cycle Assessment}

An optimistic energy balance should be attained for the addition of nano-biochar for the anaerobic digestion process in the LCA. This "cradle to grave approach" must also be beneficial from the environmental and economic perspective [152]. LCA of the biochar produced via the lignocellulosic wastes showed the GHG emission in between 20-50 g $\mathrm{CO}_{2}$-eq $\mathrm{MJ}^{-1}$; whereas for pit/shell/husk, it ranges amid 120-250 $\mathrm{g} \mathrm{CO}_{2}$-eq $\mathrm{MJ}^{-1}$ [62]. The feedstocks for biochar possessing an ash content in the range of $0-2 \%$ and having a high $\mathrm{O} / \mathrm{C}$ ratio are mainly related to the enhanced $\mathrm{GHG}$ emissions [62,84]. In addition, compared to the petro-derived fuels, the utilization of biofuels leads to $>85 \%$ reduction in GHG release, equivalent to $93 \mathrm{~g} \mathrm{CO}_{2}-\mathrm{eq} \mathrm{MJ}^{-1}$. The biochar-aided AD process offers encouraging effects in contrast with AD alone. However, further LCA studies are needed to associate and integrate the waste conversion and resource recovery processes [153]. The methodical outcomes primarily depend on the type of biomass, compositions, reaction condition, and reactor, but lack the LCA for biofuels production [154-158].

Moreover, landfills, carbon sources, and other ambiguous factors (infrastructure, transportation, and waste management) should also be considered in the LCA [5]. ReCiPe and Tool for Reduction and Assessment of Chemicals and other environmental Impacts (TRACI) is a method for the life-cycle impact analysis (LCIA) and environmental impact assessment, respectively [5]. Hence, more studies of LCA are needed to assist the optimization of methodical, financial, and environmental performances of the additive nano-biochar and its integration in AD processes.

\section{Conclusions and Prospects for Future Research}

The properties of nano-biochar are primarily dependent on the organic feedstock used and its processing. Further, it is extensively being used as a catalyst for enhancing renewable energy production. Our comprehensive evaluation of the recent literature available on biochar-amended anaerobic processes concluded the credible importance of nano-biochar from the economical, simple processing, and enhanced biogas yield. Further, the metaldoped/impregnated nano-biochar composites show more magnetization properties and recycling ability, which can reduce the costs of biochar addition. The recycling of nanobiochar composites during the AD process further leads to the loss of the methanogen population due to the digestate disposal. In addition, $\mathrm{Fe}_{2} \mathrm{O}_{3}$ and $\mathrm{Fe}_{3} \mathrm{O}_{4}$ impregnated biochar perform as electron channels for promoting the interspecies electron transfer. The enhancement in the stability and reliability of anaerobic digestion via nano-biochar addition is much significant and depicts a novel paradigm for the generation of renewable energy, resource recovery, and waste management. The biochar-aided AD process mitigates the acidification impact caused via VFAs accumulation, encouraging the electron species and microbial growth. Further, in comparison to the traditional AD process, the nano-biochar addition helps reduce the environmental impacts and cost-involved. In addition, the following are some proposals that can further improve this feature: 
(i) Numerous references report on the fed-batch operation of nano-biochar-amended AD processes. Further efforts should be made to develop continuous or semi-continuous operational modes, nano-biochar recycling, and reusability.

(ii) Prudent procedures should be developed and followed to determine the quantitative inhibition exhibited via the nano-biochar for the AD process.

(iii) Effective microbial metabolic pathways should be tracked along with the prime attention to the nano-biochar-microbe interactions, and mechanistic insights.

(iv) Techno-economic and the socio-economic analyses of the pilot- and industrial-scale plants, including the mass and energy balance assessments, are essential for the nanobiochar-amended AD process. The life-cycle and supply chain management further needs to be monitored for the overall impact of the integrated process.

(v) Exploration of DIET/IIET is highly encouraged for electron-based elucidation to enhance biogas production and further establish a pioneer avenue of research in renewable energy research.

(vi) Nano-biochar-amended co-digestion approaches need to be explored for the reduction in the reactor volume, zero-waste approach, carbon capturing, and encouraging the circular bioeconomy concept.

Author Contributions: Conceptualization and supervision: L.G., A.K. and B.S.K.; writing-original draft preparation: L.G., A.K., A.S., P.S. and Y.C.; review and editing, artwork and schemes: L.G., A.K., M.M., S.V.P. and B.S.K. All authors have read and agreed to the published version of the manuscript.

Funding: This research was supported by Chungbuk National University BK (Brain Korea) 21 FOUR (2021).

Data Availability Statement: This study did not report any original data.

Conflicts of Interest: All authors declare no competing interest with the work presented in the manuscript.

\section{References}

1. Bhatia, S.K.; Palai, A.K.; Kumar, A.; Bhatia, R.K.; Patel, A.K.; Thakur, V.K.; Yang, Y.-H. Trends in renewable energy production employing biomass-based biochar. Bioresour. Technol. 2021, 340, 125644. [CrossRef]

2. Hussain, C.M.; Singh, S.; Goswam, L. (Eds.) Chapter 13 - Biohythane production from organic waste: Challenges and technoeconomic perspective. In Waste-to-Energy Approaches Towards Zero Waste: Interdisciplinary Methods of Controlling Waste; Elsevier: Amsterdam, The Netherlands, 2022.

3. Ramanayaka, S.; Vithanage, M.; Alessi, D.S.; Liu, W.-J.; Jayasundera, A.C.A.; Ok, Y.S. Nanobiochar: Production, properties, and multifunctional applications. Environ. Sci. Nano 2020, 7, 3279-3302. [CrossRef]

4. Kushwaha, A.; Goswami, S.; Sultana, A.; Katiyar, N.K.; Athar, M.; Dubey, L.; Goswami, L.; Hussain, C.M.; Kareem, M.A. Waste biomass to biobutanol: Recent trends and advancements. In Waste-to-Energy Approaches Towards Zero Waste; Elsevier: Amsterdam, The Netherlands, 2022; pp. 393-423.

5. Kushwaha, A.; Mishra, V.; Gupta, V.; Goswami, S.; Gupta, P.K.; Singh, L.K.; Gupt, C.B.; Rakshit, K.; Goswami, L. Anaerobic digestion as a sustainable biorefinery concept for waste to energy conversion. In Waste-to-Energy Approaches Towards Zero Waste; Elsevier: Amsterdam, The Netherlands, 2022; pp. 129-163.

6. Kushwaha, A.; Yadav, A.N.; Singh, B.; Dwivedi, V.; Kumar, S.; Goswami, L.; Hussain, C.M. Life cycle assessment and technoeconomic analysis of algae-derived biodiesel: Current challenges and future prospects. In Waste-to-Energy Approaches Towards Zero Waste; Elsevier: Amsterdam, The Netherlands, 2022; pp. 343-372.

7. Kumar, M.; Kushwaha, A.; Goswami, L.; Singh, A.K.; Sikandar, M. A review on advances and mechanism for the phycoremediation of cadmium contaminated wastewater. Clean. Eng. Technol. 2021, 5, 100288. [CrossRef]

8. Gupt, C.B.; Kushwaha, A.; Prakash, A.; Chandra, A.; Goswami, L.; Sekharan, S. Mitigation of groundwater pollution: Heavy metal retention characteristics of fly ash based liner materials. In Fate and Transport of Subsurface Pollutants; Springer: Singapore, 2021; pp. 79-104.

9. Gautam, R.; Nayak, J.K.; Daverey, A.; Ghosh, U.K. Emerging sustainable opportunities for waste to bioenergy: An overview. In Waste-to-Energy Approaches Towards Zero Waste; Elsevier: Amsterdam, The Netherlands, 2022; pp. 1-55.

10. Borah, S.N.; Goswami, L.; Sen, S.; Sachan, D.; Sarma, H.; Montes, M.; Narayan, M. Selenite bioreduction and biosynthesis of selenium nanoparticles by Bacillus paramycoides SP3 isolated from coal mine overburden leachate. Environ. Pollut. 2021, 285, 117519. [CrossRef]

11. Sachan, D.; Ramesh, A.; Das, G. Green synthesis of silica nanoparticles from leaf biomass and its application to remove heavy metals from synthetic wastewater: A comparative analysis. Environ. Nanotechnol. Monit. Manag. 2021, 16, 100467. [CrossRef] 
12. Gautam, R.; Nayak, J.K.; Talapatra, K.N.; Ghosh, U.K. Assessment of different organic substrates for Bio-Electricity and BioHydrogen generation in an Integrated Bio-Electrochemical System. Mater. Today Proc. 2021. [CrossRef]

13. Lata, K.; Kushwaha, A.; Ramanathan, G. Chapter 23 - Bacterial enzymatic degradation and remediation of 2,4,6-trinitrotoluene. In Microbial and Natural Macromolecules; Academic Press: Cambridge, MA, USA, 2021; pp. 623-659. [CrossRef]

14. Sachan, D.; Das, G. Fabrication of Biochar-Impregnated $\mathrm{MnO}_{2}$ Nanocomposite: Characterization and Potential Application in Copper (II) and Zinc (II) Adsorption. J. Hazard. Toxic Radioact. Waste 2022, 26, 04021049. [CrossRef]

15. Goswami, L.; Kushwaha, A.; Goswami, S.; Sharma, Y.C.; Kim, T.; Tripathi, K.M. Nanocarbon-based-ZnO nanocomposites for supercapacitor application. In Nanostructured Zinc Oxide; Elsevier: Amsterdam, The Netherlands, 2021; pp. 553-573.

16. Goswami, S.; Kushwaha, A.; Goswami, L.; Singh, N.; Bhan, U.; Daverey, A.; Hussain, C.M. Biological treatment, recovery, and recycling of metals from waste printed circuit boards. In Environmental Management of Waste Electrical and Electronic Equipment; Elsevier: Amsterdam, The Netherlands, 2021; pp. 163-184.

17. Kushwaha, A.; Goswami, L.; Lee, J.; Sonne, C.; Brown, R.J.C.; Kim, K.-H. Selenium in soil-microbe-plant systems: Sources, distribution, toxicity, tolerance, and detoxification. Crit. Rev. Environ. Sci. Technol. 2021, 1-38. [CrossRef]

18. Kushwaha, A.; Goswami, S.; Hans, N.; Goswami, L.; Devi, G.; Deshavath, N.N.; Yadav, M.K.; Lall, A.M. An Insight into Biological and Chemical Technologies for Micropollutant Removal from Wastewater. In Fate and Transport of Subsurface Pollutants; Springer: Singapore, 2020; pp. 199-226.

19. Devi, G.; Goswami, L.; Kushwaha, A.; Sathe, S.S.; Sen, B.; Sarma, H.P. Fluoride distribution and groundwater hydrogeochemistry for drinking, domestic and irrigation in an area interfaced near Brahmaputra floodplain of North-Eastern India. Environ. Nanotechnol. Monit. Manag. 2021, 16, 100500. [CrossRef]

20. Goswami, L.; Namboodiri, M.T.; Kumar, R.V.; Pakshirajan, K.; Pugazhenthi, G. Biodiesel production potential of oleaginous Rhodococcus opacus grown on biomass gasification wastewater. Renew. Energy 2017, 105, 400-406. [CrossRef]

21. Goswami, L.; Manikandan, N.A.; Pakshirajan, K.; Pugazhenthi, G. Simultaneous heavy metal removal and anthracene biodegradation by the oleaginous bacteria Rhodococcus opacus. 3 Biotech 2017, 7, 37. [CrossRef]

22. Ma, J.; Chen, F.; Xue, S.; Pan, J.; Khoshnevisan, B.; Yang, Y.; Liu, H.; Qiu, L. Improving anaerobic digestion of chicken manure under optimized biochar supplementation strategies. Bioresour. Technol. 2021, 325, 124697. [CrossRef]

23. Zhang, T.; Yang, Y.; Liu, L.; Han, Y.; Ren, G.; Yang, G. Improved Biogas Production from Chicken Manure Anaerobic Digestion Using Cereal Residues as Co-substrates. Energy Fuels 2014, 28, 2490-2495. [CrossRef]

24. Gautam, A.; Kushwaha, A.; Rani, R. Reduction of Hexavalent Chromium [Cr (VI)] by Heavy Metal Tolerant Bacterium Alkalihalobacillus clausii CRA1 and Its Toxicity Assessment Through Flow Cytometry. Curr. Microbiol. 2022, 79, 33. [CrossRef]

25. Bi, S.; Qiao, W.; Xiong, L.; Mahdy, A.; Wandera, S.M.; Yin, D.; Dong, R. Improved high solid anaerobic digestion of chicken manure by moderate in situ ammonia stripping and its relation to metabolic pathway. Renew. Energy 2020, 146, 2380-2389. [CrossRef]

26. Pan, J.; Ma, J.; Zhai, L.; Luo, T.; Mei, Z.; Liu, H. Achievements of biochar application for enhanced anaerobic digestion: A review. Bioresour. Technol. 2019, 292, 122058. [CrossRef]

27. Deng, C.; Lin, R.; Kang, X.; Wu, B.; Wall, D.M.; Murphy, J.D. What physicochemical properties of biochar facilitate interspecies electron transfer in anaerobic digestion: A case study of digestion of whiskey by-products. Fuel 2021, 306, 121736. [CrossRef]

28. Do, M.H.; Ngo, H.H.; Guo, W.; Chang, S.W.; Nguyen, D.D.; Sharma, P.; Pandey, A.; Bui, X.T.; Zhang, X. Performance of a dual-chamber microbial fuel cell as biosensor for on-line measuring ammonium nitrogen in synthetic municipal wastewater. Sci. Total Environ. 2021, 795, 148755. [CrossRef]

29. Yadav, A.P.S.; Dwivedi, V.; Kumar, S.; Kushwaha, A.; Goswami, L.; Reddy, B.S. Cyanobacterial Extracellular Polymeric Substances for Heavy Metal Removal: A Mini Review. J. Compos. Sci. 2020, 5, 1. [CrossRef]

30. Trapero, J.; Horcajada, L.; Linares, J.J.; Lobato, J. Is microbial fuel cell technology ready? An economic answer towards industrial commercialization. Appl. Energy 2017, 185, 698-707. [CrossRef]

31. Slate, A.J.; Whitehead, K.A.; Brownson, D.A.; Banks, C.E. Microbial fuel cells: An overview of current technology. Renew. Sustain. Energy Rev. 2019, 101, 60-81. [CrossRef]

32. Xu, B.; Ge, Z.; He, Z. Sediment microbial fuel cells for wastewater treatment: Challenges and opportunities. Environ. Sci. Water Res. Technol. 2015, 1, 279-284. [CrossRef]

33. Chen, S.; Tang, J.; Fu, L.; Yuan, Y.; Zhou, S. Biochar improves sediment microbial fuel cell performance in low conductivity freshwater sediment. J. Soils Sediments 2016, 16, 2326-2334. [CrossRef]

34. Gong, L.; Amirdehi, M.A.; Miled, A.; Greener, J. Practical increases in power output from soil-based microbial fuel cells under dynamic temperature variations. Sustain. Energy Fuels 2020, 5, 671-677. [CrossRef]

35. Li, X.; Li, Y.; Zhang, X.; Zhao, X.; Sun, Y.; Weng, L.; Li, Y. Long-term effect of biochar amendment on the biodegradation of petroleum hydrocarbons in soil microbial fuel cells. Sci. Total Environ. 2019, 651, 796-806. [CrossRef]

36. Chen, Q.; Pu, W.; Hou, H.; Hu, J.; Liu, B.; Li, J.; Cheng, K.; Huang, L.; Yuan, X.; Yang, C.; et al. Activated microporous-mesoporous carbon derived from chestnut shell as a sustainable anode material for high performance microbial fuel cells. Bioresour. Technol. 2018, 249, 567-573. [CrossRef]

37. Lee, J.H.; Kim, D.S.; Yang, J.H.; Chun, Y.; Yoo, H.Y.; Han, S.O.; Lee, J.; Park, C.; Kim, S.W. Enhanced electron transfer mediator based on biochar from microalgal sludge for application to bioelectrochemical systems. Bioresour. Technol. 2018, 264, 387-390. [CrossRef] 
38. Chakraborty, I.; Bhowmick, G.D.; Ghosh, D.; Dubey, B.; Pradhan, D.; Ghangrekar, M. Novel low-cost activated algal biochar as a cathode catalyst for improving performance of microbial fuel cell. Sustain. Energy Technol. Assess. 2020, 42, 100808. [CrossRef]

39. Hemalatha, M.; Sravan, J.S.; Min, B.; Mohan, S.V. Concomitant use of Azolla derived bioelectrode as anode and hydrolysate as substrate for microbial fuel cell and electro-fermentation applications. Sci. Total Environ. 2020, 707, 135851. [CrossRef]

40. Yang, W.; Li, J.; Zhang, L.; Zhu, X.; Liao, Q. A monolithic air cathode derived from bamboo for microbial fuel cells. RSC Adv. 2017, 7, 28469-28475. [CrossRef]

41. Li, M.; Zhang, H.; Xiao, T.; Wang, S.; Zhang, B.; Chen, D.; Su, M.; Tang, J. Low-cost biochar derived from corncob as oxygen reduction catalyst in air cathode microbial fuel cells. Electrochim. Acta 2018, 283, 780-788. [CrossRef]

42. Chang, H.-C.; Gustave, W.; Yuan, Z.-F.; Xiao, Y.; Chen, Z. One-step fabrication of binder-free air cathode for microbial fuel cells by using balsa wood biochar. Environ. Technol. Innov. 2020, 18, 100615. [CrossRef]

43. Allam, F.; Elnouby, M.; El-Khatib, K.; El-Badan, D.E.; Sabry, S.A. Water hyacinth (Eichhornia crassipes) biochar as an alternative cathode electrocatalyst in an air-cathode single chamber microbial fuel cell. Int. J. Hydrogen Energy 2020, 45, 5911-5927. [CrossRef]

44. Zha, Z.; Zhang, Z.; Xiang, P.; Zhu, H.; Zhou, B.; Sun, Z.; Zhou, S. One-step preparation of eggplant-derived hierarchical porous graphitic biochar as efficient oxygen reduction catalyst in microbial fuel cells. RSC Adv. 2021, 11, 1077-1085. [CrossRef]

45. Zhang, J.; Yang, M.; Zhao, W.; Zhang, J.; Zang, L. Biohydrogen Production Amended with Nitrogen-Doped Biochar. Energy Fuels 2021, 35, 1476-1487. [CrossRef]

46. Zhao, L.; Wang, Z.; Ren, H.-Y.; Chen, C.; Nan, J.; Cao, G.-L.; Yang, S.-S.; Ren, N.-Q. Residue cornstalk derived biochar promotes direct bio-hydrogen production from anaerobic fermentation of cornstalk. Bioresour. Technol. 2021, 320, 124338. [CrossRef]

47. Rezaeitavabe, F.; Saadat, S.; Talebbeydokhti, N.; Sartaj, M.; Tabatabaei, M. Enhancing bio-hydrogen production from food waste in single-stage hybrid dark-photo fermentation by addition of two waste materials (exhausted resin and biochar). Biomass Bioenergy 2020, 143, 105846. [CrossRef]

48. Yang, G.; Wang, J. Synergistic enhancement of biohydrogen production from grass fermentation using biochar combined with zero-valent iron nanoparticles. Fuel 2019, 251, 420-427. [CrossRef]

49. Sharma, P.; Melkania, U. Biochar-enhanced hydrogen production from organic fraction of municipal solid waste using co-culture of Enterobacter aerogenes and E. coli. Int. J. Hydrogen Energy 2017, 42, 18865-18874. [CrossRef]

50. Behera, B.; Dey, B.; Balasubramanian, P. Algal biodiesel production with engineered biochar as a heterogeneous solid acid catalyst. Bioresour. Technol. 2020, 310, 123392. [CrossRef]

51. Foroutan, R.; Mohammadi, R.; Razeghi, J.; Ramavandi, B. Biodiesel production from edible oils using algal biochar $/ \mathrm{CaO} / \mathrm{K}_{2} \mathrm{CO} 3$ as a heterogeneous and recyclable catalyst. Renew. Energy 2021, 168, 1207-1216. [CrossRef]

52. Wang, Y.; Li, D.; Zhao, D.; Fan, Y.; Bi, J.; Shan, R.; Yang, J.; Luo, B.; Yuan, H.; Ling, X.; et al. Calcium-Loaded Municipal Sludge-Biochar as an Efficient and Stable Catalyst for Biodiesel Production from Vegetable Oil. ACS Omega 2020, 5, 17471-17478. [CrossRef] [PubMed]

53. Akinfalabi, S.-I.; Rashid, U.; Ngamcharussrivichai, C.; Nehdi, I.A. Synthesis of reusable biobased nano-catalyst from waste sugarcane bagasse for biodiesel production. Environ. Technol. Innov. 2020, 18, 100788. [CrossRef]

54. Bhatia, S.K.; Gurav, R.; Choi, T.-R.; Kim, H.J.; Yang, S.-Y.; Song, H.-S.; Park, J.Y.; Park, Y.-L.; Han, Y.-H.; Choi, Y.-K.; et al. Conversion of waste cooking oil into biodiesel using heterogenous catalyst derived from cork biochar. Bioresour. Technol. 2020, 302, 122872. [CrossRef] [PubMed]

55. Yang, Z.; Yang, R.; Dong, G.; Xiang, M.; Hui, J.; Ou, J.; Qin, H. Biochar Nanocomposite Derived from Watermelon Peels for Electrocatalytic Hydrogen Production. ACS Omega 2021, 6, 2066-2073. [CrossRef]

56. Jiang, C.; Yao, M.; Wang, Z.; Li, J.; Sun, Z.; Li, L.; Moon, K.-S.; Wong, C.-P. A novel flower-like architecture comprised of 3D interconnected $\mathrm{Co}-\mathrm{Al}-\mathrm{Ox} / \mathrm{Sy}$ decorated lignosulfonate-derived carbon nanosheets for flexible supercapacitors and electrocatalytic water splitting. Carbon 2021, 184, 386-399. [CrossRef]

57. Raut, S.D.; Shinde, N.M.; Nakate, Y.T.; Ghule, B.G.; Gore, S.K.; Shaikh, S.F.; Pak, J.J.; Al-Enizi, A.M.; Mane, R.S. Coconut-WaterMediated Carbonaceous Electrode: A Promising Eco-Friendly Material for Bifunctional Water Splitting Application. ACS Omega 2021, 6, 12623-12630. [CrossRef]

58. Patel, S.; Kundu, S.; Halder, P.; Marzbali, M.H.; Chiang, K.; Surapaneni, A.; Shah, K. Production of hydrogen by catalytic methane decomposition using biochar and activated char produced from biosolids pyrolysis. Int. J. Hydrogen Energy 2020, 45, 29978-29992. [CrossRef]

59. Sugiarto, Y.; Sunyoto, N.M.; Zhu, M.; Jones, I.; Zhang, D. Effect of biochar in enhancing hydrogen production by mesophilic anaerobic digestion of food wastes: The role of minerals. Int. J. Hydrogen Energy 2021, 46, 3695-3703. [CrossRef]

60. Sunyoto, N.M.; Zhu, M.; Zhang, Z.; Zhang, D. Effect of biochar addition on hydrogen and methane production in two-phase anaerobic digestion of aqueous carbohydrates food waste. Bioresour. Technol. 2016, 219, 29-36. [CrossRef]

61. Goswami, L.; Kumar, R.V.; Manikandan, N.A.; Raja, V.K.; Pugazhenthi, G. Simultaneous polycyclic aromatic hydrocarbon degradation and lipid accumulation by Rhodococcus opacus for potential biodiesel production. J. Water Process Eng. 2017, 17, 1-10. [CrossRef]

62. Kumar, M.; Dutta, S.; You, S.; Luo, G.; Zhang, S.; Show, P.L.; Sawarkar, A.D.; Singh, L.; Tsang, D.C. A critical review on biochar for enhancing biogas production from anaerobic digestion of food waste and sludge. J. Clean. Prod. 2021, 305, 127143. [CrossRef]

63. Luz, F.C.; Cordiner, S.; Manni, A.; Mulone, V.; Rocco, V. Biochar characteristics and early applications in anaerobic digestion-a review. J. Environ. Chem. Eng. 2018, 6, 2892-2909. 
64. Luo, C.; Lü, F.; Shao, L.; He, P. Application of eco-compatible biochar in naerobic digestion to relieve acid stress and promote the selective colonization of functional microbes. Water Res. 2015, 68, 710-718. [CrossRef]

65. Zhao, Z.; Zhang, Y.; Holmes, D.E.; Dang, Y.; Woodard, T.L.; Nevin, K.P.; Lovley, D.R. Potential enhancement of direct interspecies electron transfer for syntrophic metabolism of propionate and butyrate with biochar in up-flow anaerobic sludge blanket reactors. Bioresour. Technol. 2016, 209, 148-156. [CrossRef]

66. Lü, F.; Luo, C.; Shao, L.; He, P. Biochar alleviates combined stress of ammonium and acids by firstly enriching Methanosaeta and then Methanosarcina. Water Res. 2016, 90, 34-43. [CrossRef]

67. Sethupathi, S.; Ming, Z.; Rajapaksha, A.U.; Sang, R.L.; Nor, N.M.; Mohamed, A.R.; Al-Wabel, M.; Lee, S.S.; Ok, Y.S. Biochars as potential adsorbers of $\mathrm{CH}_{4}, \mathrm{CO}_{2}$ and $\mathrm{H}_{2} \mathrm{~S}$. Sustainability 2017, 9, 121. [CrossRef]

68. Creamer, A.E.; Gao, B.; Zhang, M. Carbon dioxide capture using biochar produced from sugarcane bagasse and hickory wood. Chem. Eng. J. 2014, 249, 174-179. [CrossRef]

69. Fiore, S.; Berruti, F.; Briens, C. Investigation of innovative and conventional pyrolysis of ligneous and herbaceous biomasses for biochar production. Biomass Bioenergy 2018, 119, 381-391. [CrossRef]

70. Chen, T.; Zhang, Y.; Wang, H.; Lu, W.; Zhou, Z.; Zhang, Y.; Ren, L. Influence of pyrolysis temperature on characteristics and heavy metal adsorptive performance of biochar derived from municipal sewage sludge. Bioresour. Technol. 2014, 164, 47-54. [CrossRef]

71. Rajagopal, R.; Massé, D.I.; Singh, G. A critical review on inhibition of anaerobic digestion process by excess ammonia. Bioresour. Technol. 2013, 143, 632-641. [CrossRef] [PubMed]

72. Poirier, S.; Madigou, C.; Bouchez, T.; Chapleur, O. Improving anaerobic digestion with support media: Mitigation of ammonia inhibition and effect on microbial communities. Bioresour. Technol. 2017, 235, 229-239. [CrossRef] [PubMed]

73. Shen, Y.; Forrester, S.; Koval, J.; Urgun-Demirtas, M. Yearlong semi-continuous operation of thermophilic two-stage anaerobic digesters amended with biochar for enhanced biomethane production. J. Clean. Prod. 2017, 167, 863-874. [CrossRef]

74. Su, C.; Zhao, L.; Liao, L.; Qin, J.; Lu, Y.; Deng, Q.; Chen, M.; Huang, Z. Application of biochar in a CIC reactor to relieve ammonia nitrogen stress and promote microbial community during food waste treatment. J. Clean. Prod. 2019, 209, 353-362. [CrossRef]

75. Lü, F.; Hua, Z.; Shao, L.; He, P. Loop bioenergy production and carbon sequestration of polymeric waste by integrating biochemical and thermochemical conversion processes: A conceptual framework and recent advances. Renew. Energy 2018, 124, 202-211. [CrossRef]

76. Martins, G.; Salvador, A.F.; Pereira, L.; Alves, M.M. Methane Production and Conductive Materials: A Critical Review. Environ. Sci. Technol. 2018, 52, 10241-10253. [CrossRef]

77. Park, J.-H.; Kang, H.-J.; Park, K.-H.; Park, H.-D. Direct interspecies electron transfer via conductive materials: A perspective for anaerobic digestion applications. Bioresour. Technol. 2018, 254, 300-311. [CrossRef]

78. Liu, M.; Xu, M.; Xue, Y.; Ni, W.; Huo, S.; Wu, L.; Yang, Z.; Yan, Y.-M. Efficient Capacitive Deionization Using Natural BasswoodDerived, Freestanding, Hierarchically Porous Carbon Electrodes. ACS Appl. Mater. Interfaces 2018, 10, 31260-31270. [CrossRef]

79. Barua, S.; Dhar, B.R. Advances towards understanding and engineering direct interspecies electron transfer in anaerobic digestion. Bioresour. Technol. 2017, 244, 698-707. [CrossRef]

80. Yin, C.; Shen, Y.; Yuan, R.; Zhu, N.; Yuan, H.; Lou, Z. Sludge-based biochar-assisted thermophilic anaerobic digestion of waste-activated sludge in microbial electrolysis cell for methane production. Bioresour. Technol. 2019, 284, 315-324. [CrossRef]

81. Ren, S.; Usman, M.; Tsang, D.C.W.; O-Thong, S.; Angelidaki, I.; Zhu, X.; Zhang, S.; Luo, G. Hydrochar-Facilitated Anaerobic Digestion: Evidence for Direct Interspecies Electron Transfer Mediated through Surface Oxygen-Containing Functional Groups. Environ. Sci. Technol. 2020, 54, 5755-5766. [CrossRef] [PubMed]

82. Goswami, L.; Manikandan, N.A.; Taube, J.C.R.; Pakshirajan, K.; Pugazhenthi, G. Novel waste-derived biochar from biomass gasification effluent: Preparation, characterization, cost estimation, and application in polycyclic aromatic hydrocarbon biodegradation and lipid accumulation by Rhodococcus opacus. Environ. Sci. Pollut. Res. 2019, 26, 25154-25166. [CrossRef] [PubMed]

83. Li, W.; Dang, Q.; Brown, R.C.; Laird, D.; Wright, M.M. The impacts of biomass properties on pyrolysis yields, economic and environmental performance of the pyrolysis-bioenergy-biochar platform to carbon negative energy. Bioresour. Technol. 2017, 241, 959-968. [CrossRef] [PubMed]

84. Kumar, M.; Xiong, X.; Sun, Y.; Yu, I.K.M.; Tsang, D.C.W.; Hou, D.; Gupta, J.; Bhaskar, T.; Pandey, A. Critical Review on Biochar-Supported Catalysts for Pollutant Degradation and Sustainable Biorefinery. Adv. Sustain. Syst. 2020, 4, 1900149. [CrossRef]

85. Yin, Q.; Zhang, B.; Wang, R.; Zhao, Z. Biochar as an adsorbent for inorganic nitrogen and phosphorus removal from water: A review. Environ. Sci. Pollut. Res. 2017, 24, 26297-26309. [CrossRef] [PubMed]

86. Kizito, S.; Wu, S.; Kirui, W.K.; Lei, M.; Lu, Q.; Bah, H.; Dong, R. Evaluation of slow pyrolyzed wood and rice husks biochar for adsorption of ammonium nitrogen from piggery manure anaerobic digestate slurry. Sci. Total Environ. 2015, 505, 102-112. [CrossRef]

87. Takaya, C.A.; Fletcher, L.A.; Singh, S.; Anyikude, K.U.; Ross, A.B. Phosphate and ammonium sorption capacity of biochar and hydrochar from different wastes. Chemosphere 2016, 145, 518-527. [CrossRef]

88. Zhang, Y.; Li, Z.; Mahmood, I.B. Recovery of $\mathrm{NH}_{4}{ }^{+}$by corn cob produced biochars and its potential application as soil conditioner. Front. Environ. Sci. Eng. 2014, 8, 825-834. [CrossRef] 
89. Sahota, S.; Vijay, V.K.; Subbarao, P.; Chandra, R.; Ghosh, P.; Shah, G.; Kapoor, R.; Vijay, V.; Koutu, V.; Thakur, I.S. Characterization of leaf waste based biochar for cost effective hydrogen sulphide removal from biogas. Bioresour. Technol. 2018, 250, 635-641. [CrossRef]

90. Kanjanarong, J.; Giri, B.S.; Jaisi, D.P.; de Oliveira, F.R.; Boonsawang, P.; Chaiprapat, S.; Singh, R.; Balakrishna, A.; Khanal, S.K. Removal of hydrogen sulfide generated during anaerobic treatment of sulfate-laden wastewater using biochar: Evaluation of efficiency and mechanisms. Bioresour. Technol. 2017, 234, 115-121. [CrossRef]

91. Chacón, F.J.; Sanchez-Monedero, M.; Lezama, L.; Cayuela, M.L. Enhancing biochar redox properties through feedstock selection, metal preloading and post-pyrolysis treatments. Chem. Eng. J. 2020, 395, 125100. [CrossRef]

92. Klüpfel, L.; Keiluweit, M.; Kleber, M.; Sander, M. Redox Properties of Plant Biomass-Derived Black Carbon (Biochar). Environ. Sci. Technol. 2014, 48, 5601-5611. [CrossRef] [PubMed]

93. Kumar, M.; Xiong, X.; Wan, Z.; Sun, Y.; Tsang, D.C.; Gupta, J.; Gao, B.; Cao, X.; Tang, J.; Ok, Y.S. Ball milling as a mechanochemical technology for fabrication of novel biochar nanomaterials. Bioresour. Technol. 2020, 312, 123613. [CrossRef] [PubMed]

94. Joseph, S.; Husson, O.; Graber, E.R.; Van Zwieten, L.; Taherymoosavi, S.; Thomas, T.; Nielsen, S.; Ye, J.; Pan, G.; Chia, C.; et al. The Electrochemical Properties of Biochars and How They Affect Soil Redox Properties and Processes. Agronomy 2015, 5, 322-340. [CrossRef]

95. Dieguez-Alonso, A.; Anca-Couce, A.; Frišták, V.; Moreno-Jiménez, E.; Bacher, M.; Bucheli, T.D.; Cimò, G.; Conte, P.; Hagemann, N.; Haller, A.; et al. Designing biochar properties through the blending of biomass feedstock with metals: Impact on oxyanions adsorption behavior. Chemosphere 2019, 214, 743-753. [CrossRef] [PubMed]

96. Masebinu, S.; Akinlabi, E.; Muzenda, E.; Aboyade, A. A review of biochar properties and their roles in mitigating challenges with anaerobic digestion. Renew. Sustain. Energy Rev. 2019, 103, 291-307. [CrossRef]

97. Indren, M.; Birzer, C.H.; Kidd, S.P.; Hall, T.; Medwell, P.R. Effects of biochar parent material and microbial pre-loading in biochar-amended high-solids anaerobic digestion. Bioresour. Technol. 2020, 298, 122457. [CrossRef]

98. Shen, Y.; Linville, J.L.; Ignacio-de Leon, P.A.A.; Schoene, R.P.; Urgun-Demirtas, M. Towards a sustainable paradigm of waste-toenergy process: Enhanced anaerobic digestion of sludge with woody biochar. J. Clean. Prod. 2016, 135, 1054-1064. [CrossRef]

99. Li, H.; Feng, K. Life cycle assessment of the environmental impacts and energy efficiency of an integration of sludge anaerobic digestion and pyrolysis. J. Clean. Prod. 2018, 195, 476-485. [CrossRef]

100. Li, H.; Dong, X.; da Silva, E.B.; de Oliveira, L.M.; Chen, Y.; Ma, L.Q. Echanisms of metal sorption by biochars: Biochar characteristics and modifications. Chemosphere 2017, 178, 466-478. [CrossRef]

101. Shanmugam, S.R.; Adhikari, S.; Nam, H.; Sajib, S.K. Effect of bio-char on methane generation from glucose and aqueous phase of algae liquefaction using mixed anaerobic cultures. Biomass Bioenergy 2018, 108, 479-486. [CrossRef]

102. Fagbohungbe, M.; Herbert, B.M.; Hurst, L.; Li, H.; Usmani, S.Q.; Semple, K.T. Impact of biochar on the anaerobic digestion of citrus peel waste. Bioresour. Technol. 2016, 216, 142-149. [CrossRef]

103. Viggi, C.C.; Simonetti, S.; Palma, E.; Pagliaccia, P.; Braguglia, C.; Fazi, S.; Baronti, S.; Navarra, M.A.; Pettiti, I.; Koch, C.; et al. Enhancing methane production from food waste fermentate using biochar: The added value of electrochemical testing in pre-selecting the most effective type of biochar. Biotechnol. Biofuels 2017, 10, 303. [CrossRef] [PubMed]

104. Qin, Y.; Wang, H.; Li, X.; Cheng, J.J.; Wu, W. Improving methane yield from organic fraction of municipal solid waste (OFMSW) with magnetic rice-straw biochar. Bioresour. Technol. 2017, 245, 1058-1066. [CrossRef]

105. Wang, C.; Liu, Y.; Gao, X.; Chen, H.; Xu, X.; Zhu, L. Role of biochar in the granulation of anaerobic sludge and improvement of electron transfer characteristics. Bioresour. Technol. 2018, 268, 28-35. [CrossRef] [PubMed]

106. Qiu, L.; Deng, Y.; Wang, F.; Davaritouchaee, M.; Yao, Y. A review on biochar-mediated anaerobic digestion with enhanced methane recovery. Renew. Sustain. Energy Rev. 2019, 115, 109373. [CrossRef]

107. Ren, Y.; Yu, M.; Wu, C.; Wang, Q.; Gao, M.; Huang, Q.; Liu, Y. A comprehensive review on food waste anaerobic digestion: Research updates and tendencies. Bioresour. Technol. 2018, 247, 1069-1076. [CrossRef]

108. Fotidis, I.; Karakashev, D.B.; Kotsopoulos, T.; Martzopoulos, G.G.; Angelidaki, I. Effect of ammonium and acetate on methanogenic pathway and methanogenic community composition. FEMS Microbiol. Ecol. 2013, 83, 38-48. [CrossRef]

109. Jang, H.M.; Choi, Y.K.; Kan, E. Effects of dairy manure-derived biochar on psychrophilic, mesophilic and ther-mophilic anaerobic digestions of dairy manure. Bioresour. Technol. 2018, 250, 927-931. [CrossRef]

110. Linville, J.L.; Shen, Y.; Leon, P.A.I.-D.; Schoene, R.P.; Urgun-Demirtas, M. In-situ biogas upgrading during anaerobic digestion of food waste amended with walnut shell biochar at bench scale. Waste Manag. Res. J. A Sustain. Circ. Econ. 2017, 35, 669-679. [CrossRef]

111. Pan, J.; Ma, J.; Zhai, L.; Liu, H. Enhanced methane production and syntrophic connection between microorganisms during semi-continuous anaerobic digestion of chicken manure by adding biochar. J. Clean. Prod. 2019, 240, 118178. [CrossRef]

112. Zhang, D.; Li, W.; Hou, C.; Shen, J.; Jiang, X.; Sun, X.; Li, J.; Han, W.; Wang, L.; Liu, X. Aerobic granulation accelerated by biochar for the treatment of refractory wastewater. Chem. Eng. J. 2017, 314, 88-97. [CrossRef]

113. Sun, D.; Hale, L.; Crowley, D. Nutrient supplementation of pinewood biochar for use as a bacterial inoculum carrier. Biol. Fertil. Soils 2016, 52, 515-522. [CrossRef]

114. Dang, Y.; Holmes, D.E.; Zhao, Z.; Woodard, T.L.; Zhang, Y.; Sun, D.; Wang, L.-Y.; Nevin, K.P.; Lovley, D.R. Enhancing anaerobic digestion of complex organic waste with carbon-based conductive materials. Bioresour. Technol. 2016, 220, 516-522. [CrossRef] [PubMed] 
115. Wang, G.; Li, Q.; Gao, X.; Wang, X.C. Sawdust-Derived Biochar Much Mitigates VFAs Accumulation and Improves Microbial Activities To Enhance Methane Production in Thermophilic Anaerobic Digestion. ACS Sustain. Chem. Eng. 2018, 7, 2141-2150. [CrossRef]

116. Xu, F.; Li, Y.; Ge, X.; Yang, L.; Li, Y. Anaerobic digestion of food waste-Challenges and opportunities. Bioresour. Technol. 2018, 247, 1047-1058. [CrossRef]

117. Zhang, J.; Zhao, W.; Zhang, H.; Wang, Z.; Fan, C.; Zang, L. Recent achievements in enhancing anaerobic digestion with carbon-based functional materials. Bioresour. Technol. 2018, 266, 555-567. [CrossRef]

118. Roden, E.E.; Kappler, A.; Bauer, I.; Jiang, J.; Paul, A.; Stoesser, R.; Konishi, H.; Xu, H. Extracellular electron transfer through microbial reduction of solid-phase humic substances. Nat. Geosci. 2010, 3, 417-421. [CrossRef]

119. McGlynn, S.E.; Chadwick, G.; Kempes, C.P.; Orphan, V. Single cell activity reveals direct electron transfer in methanotrophic consortia. Nature 2015, 526, 531-535. [CrossRef]

120. Schink, B.; Montag, D.; Keller, A.; Müller, N. Hydrogen or formate: Alternative key players in methanogenic deg-radation. Environ. Microbiol. Rep. 2017, 9, 189-202. [CrossRef]

121. Chiappero, M.; Norouzi, O.; Hu, M.; Demichelis, F.; Berruti, F.; Di Maria, F.; Fiore, S. Review of biochar role as ad-ditive in anaerobic digestion processes. Renew. Sustain. Energy Rev. 2020, 131, 110037. [CrossRef]

122. Lovley, D.R. Happy together: Microbial communities that hook up to swap electrons. ISME J. 2017, 11, 327-336. [CrossRef] [PubMed]

123. Martínez, E.J.; Rosas, J.G.; Sotres, A.; Moran, A.; Cara-Jiménez, J.; Sánchez, M.E.; Gómez, X. Codigestion of sludge and citrus peel wastes: Evaluating the effect of biochar addition on microbial communities. Biochem. Eng. J. 2018, 137, 314-325. [CrossRef]

124. Jadhav, P.; Muhammad, N.; Bhuyar, P.; Krishnan, S.; Razak, A.S.A.; Zularisam, A.; Nasrullah, M. A review on the impact of conductive nanoparticles (CNPs) in anaerobic digestion: Applications and limitations. Environ. Technol. Innov. 2021, $23,101526$. [CrossRef]

125. Lin, R.; Deng, C.; Cheng, J.; Xia, A.; Lens, P.N.L.; Jackson, S.A.; Dobson, A.D.; Murphy, J.D. Graphene Facilitates Biomethane Production from Protein-Derived Glycine in Anaerobic Digestion. Iscience 2018, 10, 158-170. [CrossRef]

126. Li, P.; Li, W.; Sun, M.; Xu, X.; Zhang, B.; Sun, Y. Evaluation of Biochemical Methane Potential and Kinetics on the Anaerobic Digestion of Vegetable Crop Residues. Energies 2019, 12, 26. [CrossRef]

127. Kumar, S.S.; Ghosh, P.; Kataria, N.; Kumar, D.; Thakur, S.; Pathania, D.; Singh, L. The role of conductive nano-particles in anaerobic digestion: Mechanism, current status and future perspectives. Chemosphere 2021, 280, 130601. [CrossRef] [PubMed]

128. Pramanik, S.K.; Suja, F.B.; Porhemmat, M.; Pramanik, B.K. Performance and kinetic model of a single-stage an-aerobic digestion system operated at different successive operating stages for the treatment of food waste. Processes 2019, 7, 600. [CrossRef]

129. Budiyono, I.S.; Sumardiono, S. Kinetic model of biogas yield production from vinasse at various initial pH: Com-parison between modified Gompertz model and first order kinetic model. Res. J. Appl. Sci. Eng. Technol. 2014, 7, 2798-2805.

130. Huiliñir, C.; Quintriqueo, A.; Antileo, C.; Montalvo, S. Methane production from secondary paper and pulp sludge: Effect of natural zeolite and modeling. Chem. Eng. J. 2014, 257, 131-137. [CrossRef]

131. Muloiwa, M.; Nyende-Byakika, S.; Dinka, M. Comparison of unstructured kinetic bacterial growth models. S. Afr. J. Chem. Eng. 2020, 33, 141-150. [CrossRef]

132. Buswell, A.M.; Hatfield, W.D. Anaerobic Fermentations. Bulletin No. 32. 1939. Available online: https://www.ideals.illinois. edu/bitstream/handle/2142/94555/ISWSB-32.pdf? sequence=1 (accessed on 26 January 2021).

133. Abuabdou, S.M.; Ahmad, W.; Aun, N.C.; Bashir, M.J. A review of anaerobic membrane bioreactors (AnMBR) for the treatment of highly contaminated landfill leachate and biogas production: Effectiveness, limitations and future perspectives. J. Clean. Prod. 2020, 255, 120215. [CrossRef]

134. González, J.; Sánchez, M.E.; Gómez, X. Enhancing Anaerobic Digestion: The Effect of Carbon Conductive Materials. C 2018, 4, 59. [CrossRef]

135. Monlau, F.; Francavilla, M.; Sambusiti, C.; Antoniou, N.; Solhy, A.; Libutti, A.; Zabaniotou, A.; Barakat, A.; Monteleone, M. Toward a functional integration of anaerobic digestion and pyrolysis for a sustainable resource management. Comparison between solid-digestate and its derived pyrochar as soil amendment. Appl. Energy 2016, 169, 652-662. [CrossRef]

136. Elsayed, M.; Ran, Y.; Ai, P.; Azab, M.; Mansour, A.; Jin, K.; Zhang, Y.; Abomohra, A.E.-F. Innovative integrated approach of biofuel production from agricultural wastes by anaerobic digestion and black soldier fly larvae. J. Clean. Prod. 2020, $263,121495$. [CrossRef]

137. Giwa, A.S.; Xu, H.; Chang, F.; Zhang, X.; Ali, N.; Yuan, J.; Wang, K. Pyrolysis coupled anaerobic digestion process for food waste and recalcitrant residues: Fundamentals, challenges, and considerations. Energy Sci. Eng. 2019, 7, 2250-2264. [CrossRef]

138. Song, J.; Wang, Y.; Zhang, S.; Song, Y.; Xue, S.; Liu, L.; Lvy, X.; Wang, X.; Yang, G. Coupling biochar with anaerobic digestion in a circular economy perspective: A promising way to promote sustainable energy, environment and agriculture development in China. Renew. Sustain. Energy Rev. 2021, 144, 110973. [CrossRef]

139. Deng, C.; Lin, R.; Kang, X.; Wu, B.; O'Shea, R.; Murphy, J.D. Improving gaseous biofuel yield from seaweed through a cascading circular bioenergy system integrating anaerobic digestion and pyrolysis. Renew. Sustain. Energy Rev. 2020, 128, 109895. [CrossRef]

140. Shen, Y.; Linville, J.L.; Urgun-Demirtas, M.; Schoene, R.P.; Snyder, S.W. Producing pipeline-quality biomethane via anaerobic digestion of sludge amended with corn stover biochar with in-situ $\mathrm{CO}_{2}$ removal. Appl. Energy 2015, 158, 300-309. [CrossRef] 
141. Hübner, T.; Mumme, J. Integration of pyrolysis and anaerobic digestion-Use of aqueous liquor from digestate pyrolysis for biogas production. Bioresour. Technol. 2015, 183, 86-92. [CrossRef] [PubMed]

142. Li, S.; Chan, C.Y.; Sharbatmaleki, M.; Trejo, H.; Delagah, S. Engineered Biochar Production and Its Potential Benefits in a Closed-Loop Water-Reuse Agriculture System. Water 2020, 12, 2847. [CrossRef]

143. Zhao, Z.; Zhang, Y.; Woodard, T.L.; Nevin, K.P.; Lovley, D.R. Enhancing syntrophic metabolism in up-flow an-aerobic sludge blanket reactors with conductive carbon materials. Bioresour. Technol. 2015, 191, 140-145. [CrossRef]

144. Khalid, Z.B.; Siddique, M.N.I.; Nayeem, A.; Adyel, T.M.; Ismail, S.B.; Ibrahim, M.Z. Biochar application as sustainable precursors for enhanced anaerobic digestion: A systematic Review. J. Environ. Chem. Eng. 2021, 9, 105489. [CrossRef]

145. Sahoo, K.; Bilek, E.; Bergman, R.; Mani, S. Techno-economic analysis of producing solid biofuels and biochar from forest residues using portable systems. Appl. Energy 2019, 235, 578-590. [CrossRef]

146. Kumar, A.N.; Dissanayake, P.D.; Masek, O.; Priya, A.; Lin, C.S.K.; Ok, Y.S.; Kim, S.-H. Recent trends in biochar integration with anaerobic fermentation: Win-win strategies in a closed-loop. Renew. Sustain. Energy Rev. 2021, 149, 111371. [CrossRef]

147. Peng, W.; Pivato, A. Sustainable Management of Digestate from the Organic Fraction of Municipal Solid Waste and Food Waste Under the Concepts of Back to Earth Alternatives and Circular Economy. Waste Biomass Valorization 2019, 10, 465-481. [CrossRef]

148. Opatokun, S.A.; Kan, T.; Al Shoaibi, A.; Srinivasakannan, C.; Strezov, V. Characterization of Food Waste and Its Digestate as Feedstock for Thermochemical Processing. Energy Fuels 2016, 30, 1589-1597. [CrossRef]

149. Zhao, W.; Yang, H.; He, S.; Zhao, Q.; Wei, L. A review of biochar in anaerobic digestion to improve biogas production: Performances, mechanisms and economic assessments. Bioresour. Technol. 2021, 341, 125797. [CrossRef]

150. González, R.; González, J.; Rosas, J.; Smith, R.; Gómez, X. Biochar and Energy Production: Valorizing Swine Manure through Coupling Co-Digestion and Pyrolysis. C 2020, 6, 43. [CrossRef]

151. Ambaye, T.G.; Rene, E.R.; Nizami, A.S.; Dupont, C.; Vaccari, M.; van Hullebusch, E.D. Beneficial role of biochar addition on the anaerobic digestion of food waste: A systematic and critical review of the operational parameters and mech-anisms. J. Environ. Manag. 2021, 290, 112537. [CrossRef] [PubMed]

152. Moreira, M.T.; Noya, I.; Feijoo, G. The prospective use of biochar as adsorption matrix-A review from a lifecycle perspective. Bioresour. Technol. 2017, 246, 135-141. [CrossRef] [PubMed]

153. Deshavath, N.N.; Mogili, N.V.; Dutta, M.; Goswami, L.; Kushwaha, A.; Veeranki, V.D.; Goud, V.V. Role of lig-nocellulosic bioethanol in the transportation sector: Limitations and advancements in bioethanol production from lignocellulosic biomass. In Waste-to-Energy Approaches Towards Zero Waste; Elsevier: Amsterdam, The Netherlands, 2022; pp. 57-85.

154. Bajgai, R.C.; Tamang, D.T.; Kushwaha, A.; Goswami, L. Strategic consideration as feedstock resource for biofuel production as a holistic approach to control invasive plant species. In Waste-to-Energy Approaches Towards Zero Waste; Elsevier: Amsterdam, The Netherlands, 2022; pp. 245-268.

155. Gautam, A.; Kushwaha, A.; Rani, R. Microbial remediation of hexavalent chromium: An eco-friendly strategy for the remediation of chromium-contaminated wastewater. In The Future of Effluent Treatment Plants; Elsevier: Amsterdam, The Netherlands, 2021; pp. 361-384.

156. Goswami, L.; Pakshirajan, K.; Pugazhenthi, G. Biological treatment of biomass gasification wastewater using hy-drocarbonoclastic bacterium Rhodococcus opacus in an up-flow packed bed bioreactor with a novel waste-derived nano-biochar based bio-support material. J. Clean. Prod. 2020, 256, 120253. [CrossRef]

157. Singh, A.; Kushwaha, A.; Goswami, S.; Tripathi, A.; Bhasney, S.M.; Goswami, L.; Hussain, C.M. Roadmap from microalgae to biorefinery: A Circular Bioeconomy approach. In Emerging Trades to Approaching Zero Waste; Elsevier: Amsterdam, The Netherlands, 2022; pp. 373-392.

158. Anupama; Khare, P. A comprehensive evaluation of inherent properties and applications of nano-biochar prepared from different methods and feedstocks. J. Clean. Prod. 2021, 320, 128759. [CrossRef] 